\title{
Cyclic Sulfamidates as Precursors to Alkylidene Pyrrolidines and Piperidines
}

\author{
John F. Bower, ${ }^{a}$ Peter Szeto ${ }^{b}$ and Timothy Gallagher ${ }^{a^{*}}$ \\ ${ }^{a}$ School of Chemistry, University of Bristol, Bristol, BS8 1TS, United Kingdom. \\ ${ }^{b}$ Chemical Development, GlaxoSmithKline, Medicines Research Centre, Stevenage, SG1 2NY, \\ United Kingdom.
}

\section{Supporting Information}
Contents
Page 1
(A) General experimental details
Page 2
(B) Experimental Procedures
Page 11
(C) References relevant to Supporting Information
Page 12
(D) Copies of ${ }^{1} \mathrm{H}$ and ${ }^{13} \mathrm{C}$ NMR spectra

\section{(A) General experimental details}

Starting materials sourced from commercial suppliers were used as received. Dry solvents, where necessary, were obtained by distillation using standard procedures or by passage through a column of anhydrous alumina using equipment from Anhydrous Engineering based on the Grubbs' design. Petrol refers to the fraction of petroleum ether boiling in the range of 40-60 ${ }^{\circ} \mathrm{C}$. The removal of solvents in vacuo was achieved using both a Büchi rotary evaporator (bath temperatures up to $40{ }^{\circ} \mathrm{C}$ ) at a pressure of either $15 \mathrm{mmHg}$ (diaphragm pump) or $0.1 \mathrm{mmHg}$ (oil pump), as appropriate, and a high vacuum line at room temperature. Reactions requiring anhydrous conditions were run under an atmosphere of dry nitrogen; glassware, syringes and needles were either flame dried immediately prior to use or placed in an oven $\left(150{ }^{\circ} \mathrm{C}\right)$ for at least $2 \mathrm{~h}$ and allowed to cool either in a desiccator or under an atmosphere of dry nitrogen; liquid reagents, solutions or solvents were added via syringe through rubber septa; solid reagents were added via Schlenk type adapters. Commercially available Merck Kieselgel $60 \mathrm{~F}_{254}$ aluminium backed plates were used for TLC analysis. Visualisation was achieved by either UV fluorescence, acidic $\mathrm{KMnO}_{4}$ solution and heat, ninhydrin stain and heat, ammonium molybdate solution and heat or iodine vapour. Flash column chromatography (FCC) was performed using Fluorochem 60 silica: 230-400 mesh (40-63 $\mu \mathrm{m}$ ). The crude material was applied to the column as a solution in $\mathrm{CH}_{2} \mathrm{Cl}_{2}$ or by preadsorption onto silica, as appropriate. Melting points were determined using a Reichert 
melting point table and temperature controller and are uncorrected. Optical rotations were measured using a Perkin-Elmer 241 polarimeter. Infra-red spectra were recorded in the range 4000-600 $\mathrm{cm}^{-1}$ on a Perkin Elmer Spectrum either as neat films or solids compressed onto a diamond window. Abbreviations used are: w (weak), m (medium), s (strong) and br (broad). NMR spectra were recorded on a JEOL GX270, JEOL GX400, JEOL Lambda 300, JEOL Eclipse 400, JEOL Eclipse 300 or JEOL Alpha 500 spectrometer. Chemical shifts are quoted in parts per million (ppm); ${ }^{1} \mathrm{H}$ NMR spectra are referenced to TMS or residual protium of the deuterated solvent; ${ }^{13} \mathrm{C}$ NMR are referenced to TMS or the deuterated solvent. Coupling constants $(J)$ are quoted to the nearest $0.5 \mathrm{~Hz}$. Other abbreviations used are: s (singlet), d (doublet), t (triplet), q (quartet), m (multiplet) and br (broad). Assignments of ${ }^{1} \mathrm{H}$ NMR and ${ }^{13} \mathrm{C}$ NMR signals were made where possible, using COSY, DEPT, HMQC and HMBC experiments. Where mixtures of isomers (e.g. diastereomers) have been characterised together, they are referred to as $A$ and $B$. Mass spectra were determined by the University of Bristol mass spectrometry service by either electron impact (EI) or chemical ionisation (CI) using a Fisons VG Analytical Autospec spectrometer, or by electrospray ionisation (ESI) using a Brüker Daltonics Apex IV spectrometer. N.B. Compound numbers used in the Supporting Information correspond to those used in the main paper.

\section{(B) Experimental Procedures}
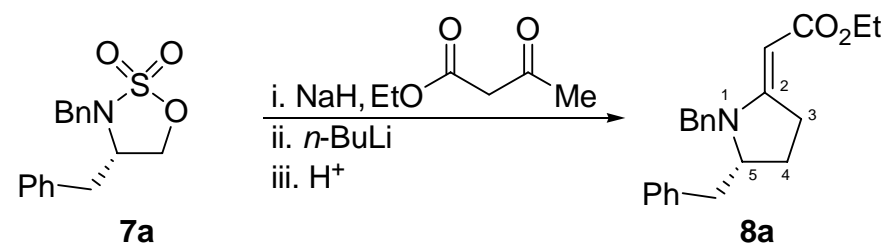

[(R)-1,5-Dibenzylpyrrolidin-(2E)-ylidene]acetic acid ethyl ester (8a): To an ice-cooled (0 $\left.{ }^{\circ} \mathrm{C}\right)$ solution of ethyl acetoacetate $(420 \mu \mathrm{L}, 3.30 \mathrm{mmol})$ in anhydrous THF $(10 \mathrm{~mL})$ was added, portionwise, $\mathrm{NaH}$ (60 \% dispersion in mineral oil, $132 \mathrm{mg}, 3.30 \mathrm{mmol}$ ) and the mixture was stirred for 15 minutes. $n$-BuLi in hexanes (1.6 M, $3.30 \mathrm{mmol}$ ) was then added dropwise and the mixture was stirred at $0{ }^{\circ} \mathrm{C}$ for a further 15 minutes. Cyclic sulfamidate $7 \mathbf{a}$ (500 mg, $1.65 \mathrm{mmol}$ ) was then added and the mixture was stirred at r.t. for $22 \mathrm{~h}$. Aqueous 5 $\mathrm{M} \mathrm{HCl}(3 \mathrm{~mL})$ was added and the mixture was stirred at r.t. for $4 \mathrm{~h}$ prior to neutralisation with saturated aq. $\mathrm{NaHCO}_{3}$. The mixture was extracted with $\mathrm{CH}_{2} \mathrm{Cl}_{2}(3 \times 40 \mathrm{~mL})$ and the combined organic extracts were dried $\left(\mathrm{Na}_{2} \mathrm{SO}_{4}\right)$ and concentrated in vacuo. The residue was purified by FCC (EtOAc-hexanes 1:4) to afford the title compound 8a (457 mg, 79 \%) as a colorless oil; $[\alpha]_{\mathrm{D}}{ }^{20}-42.9$ (c = 0.6, $\left.\mathrm{CHCl}_{3}\right) ; v_{\max } / \mathrm{cm}^{-1}$ (film) 2978 (m), 1681 (s), 1590 (s), 
1580 (s), 1453 (m), 1131 (s), 1063 (m); $\delta_{\mathrm{H}}\left(400 \mathrm{MHz}, \mathrm{CDCl}_{3}\right.$ ) 1.19-1.25 (3H, m, $\left.\mathrm{CO}_{2} \mathrm{CH}_{2} \underline{\mathrm{C}}_{3}\right), 1.73-1.82(1 \mathrm{H}, \mathrm{m}, \mathrm{C} 4-\underline{\mathrm{H}}), 1.87-1.98(1 \mathrm{H}, \mathrm{m}, \mathrm{C} 4-\underline{\mathrm{H}}), 2.51(1 \mathrm{H}, \mathrm{dd}, J=13.0$ and 9.5, C5- $\underline{\mathrm{H}}_{2} \mathrm{Ph}$ ), 2.97 (1H, dd, $J=13.0$ and 4.5, C5- $\underline{\mathrm{H}}_{2} \mathrm{Ph}$ ), 3.00-3.10 (1H, m, C3- $\underline{\mathrm{H}}$ ), 3.25 (1H, ddd, $J=17.5,9.5$ and 5.0, C3- $\underline{\mathrm{H}}), 3.72-3.80(1 \mathrm{H}, \mathrm{m}, \mathrm{C}-\underline{\mathrm{H}}), 4.02-4.13(2 \mathrm{H}, \mathrm{m}$, $\left.\mathrm{CO}_{2} \mathrm{CH}_{2} \mathrm{CH}_{3}\right), 4.28\left(1 \mathrm{H}, \mathrm{d}, J=16.0, \mathrm{NC}_{2} \mathrm{Ph}\right), 4.54\left(1 \mathrm{H}, \mathrm{d}, J=16.0, \mathrm{NC}_{2} \mathrm{Ph}\right), 4.64(1 \mathrm{H}, \mathrm{s}$, C2-C $\underline{H}), 7.05$ (2H, d, $J=7.5$, ArCH), 7.17-7.35 (8H, m, ArC프); $\delta_{\mathrm{C}}\left(100 \mathrm{MHz}, \mathrm{CDCl}_{3}\right) 14.8$

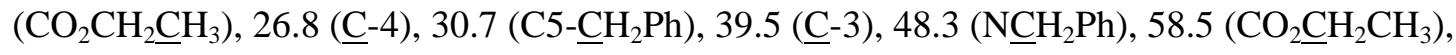

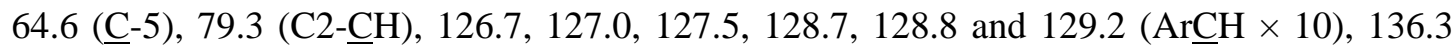
and $137.7(\mathrm{ArC} \times 2)$, 165.6 and $169.6\left(\underline{\mathrm{C}}-2\right.$ and $\left.\mathrm{CO}_{2} \mathrm{CH}_{2} \mathrm{CH}_{3}\right)$; HRMS: $\left(\mathrm{ESI}^{+}\right)$Found: $[\mathrm{M}+\mathrm{Na}]^{+}$358.1783, $\mathrm{C}_{22} \mathrm{H}_{25} \mathrm{NO}_{2} \mathrm{Na}$ requires 358.1778.

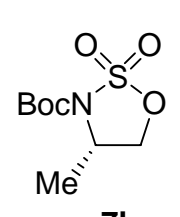

$7 b$

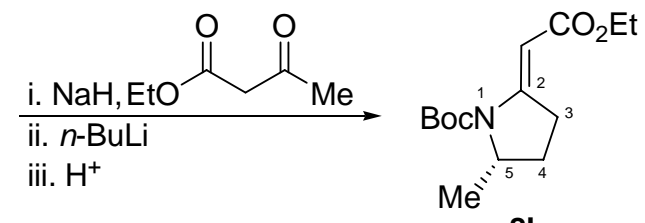

$8 b$

(S)-2-[1-Ethoxycarbonylmeth-(E)-ylidene]-5-methylpyrrolidine-1-carboxylic acid tertbutyl ester (8b): To an ice-cooled $\left(0{ }^{\circ} \mathrm{C}\right)$ solution of ethyl acetoacetate $(107 \mu \mathrm{L}, 0.84 \mathrm{mmol})$ in anhydrous THF (2.54 mL) was added, portionwise, NaH (60 \% dispersion in mineral oil, $34 \mathrm{mg}, 0.84 \mathrm{mmol}$ ) and the mixture was stirred for 15 minutes. $n$-BuLi in hexanes (2.5 M, $0.84 \mathrm{mmol}$ ) was then added dropwise and the mixture was stirred at $0{ }^{\circ} \mathrm{C}$ for a further 15 minutes. Cyclic sulfamidate $\mathbf{7 b}(100 \mathrm{mg}, 0.42 \mathrm{mmol})$ was then added and the mixture was stirred at r.t. for 20 h. Aq. $5 \mathrm{M} \mathrm{HCl}(0.42 \mathrm{~mL})$ was added and the mixture was stirred at r.t. for $1 \mathrm{~h}$ prior to neutralisation with saturated aq. $\mathrm{NaHCO}_{3}$. The mixture was extracted with $\mathrm{CH}_{2} \mathrm{Cl}_{2}$ $(3 \times 10 \mathrm{~mL})$ and the combined organic extracts were dried $\left(\mathrm{Na}_{2} \mathrm{SO}_{4}\right)$ and concentrated in vacuo. The residue was purified by FCC (EtOAc-hexanes 1:5) to afford the title compound $\mathbf{8 b}$ (86 mg, $76 \%$ ) as a colorless, crystalline solid; m.p. $79-81{ }^{\circ} \mathrm{C}\left(\mathrm{Et}_{2} \mathrm{O}\right.$-hexanes); $[\alpha]_{\mathrm{D}}{ }^{20}+61.8(\mathrm{c}$ = 1.1, $\left.\mathrm{CHCl}_{3}\right) ; ; v_{\max } / \mathrm{cm}^{-1}$ (film) 2977 (m), 1718 (s), 1616 (s), 1378 (s), 1314 (m), $1292(\mathrm{~m})$, 1129 (s); $\delta_{\mathrm{H}}\left(400 \mathrm{MHz}, \mathrm{CDCl}_{3}\right)$ 1.20-1.28 (6H, m, $\mathrm{CO}_{2} \mathrm{CH}_{2} \mathrm{C}_{3}$ and C5- $\left.\underline{\mathrm{H}}_{3}\right), 1.49-1.71(10 \mathrm{H}$, m, $\mathrm{NCO}_{2} \mathrm{C}\left(\mathrm{C}_{\underline{H}_{3}}\right)_{3}$ and $\left.\mathrm{C} 4-\underline{\mathrm{H}}\right), 1.93-2.05(1 \mathrm{H}, \mathrm{m}, \mathrm{C} 4-\underline{\mathrm{H}}), 2.90-3.01(1 \mathrm{H}, \mathrm{m}, \mathrm{C} 3-\underline{\mathrm{H}}), 3.43-3.53$ (1H, m, C3- $\underline{\mathrm{H}})$, 4.08-4.16 (2H, m, $\left.\mathrm{CO}_{2} \mathrm{C}_{2} \mathrm{CH}_{3}\right), 4.25-4.34$ (1H, m, C5- $\left.\underline{\mathrm{H}}\right), 6.49$ (1H, s, C2$\mathrm{C} \underline{\mathrm{H}}) ; \delta_{\mathrm{C}}\left(100 \mathrm{MHz}, \mathrm{CDCl}_{3}\right) 14.4$ and $19.5\left(\mathrm{CO}_{2} \mathrm{CH}_{2} \mathrm{CH}_{3}\right.$ and $\left.\mathrm{C} 5-\underline{\mathrm{CH}_{3}}\right), 28.2$ (2 signals) $\left(\mathrm{NCO}_{2} \mathrm{C}\left(\underline{\mathrm{CH}}_{3}\right)_{3}\right.$ and $\left.\underline{\mathrm{C}}-3\right), 29.8$ (드) 4$), 57.0(\underline{\mathrm{C}}-5), 59.1\left(\mathrm{CO}_{2} \mathrm{CH}_{2} \mathrm{CH}_{3}\right), 81.8\left(\mathrm{CO}_{2} \underline{\mathrm{C}}\left(\mathrm{CH}_{3}\right)_{3}\right)$, 96.2 (C2- $\underline{\mathrm{CH}}), 151.7\left(\mathrm{CO}_{2} \mathrm{C}\left(\mathrm{CH}_{3}\right)_{3}\right), 157.1$ and 169.0 (C-2 and $\left.\mathrm{CO}_{2} \mathrm{CH}_{2} \mathrm{CH}_{3}\right)$; HRMS: $\left(\mathrm{ESI}^{+}\right.$) Found: [M+Na] $]^{+}$292.1512, $\mathrm{C}_{14} \mathrm{H}_{23} \mathrm{NO}_{4} \mathrm{Na}$ requires 292.1519. 
<smiles>C[C@@H]1[C@H](c2ccccc2)OS(=O)(=O)N1C</smiles>

7c

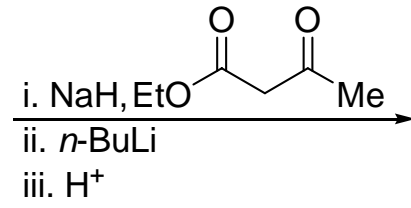

iii. $\mathrm{H}^{+}$

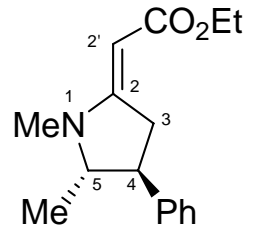

8c

[(4S,5S)-1,5-Dimethyl-4-phenylpyrrolidin-(2E)-ylidene]acetic acid ethyl ester (8c): To an ice-cooled $\left(0{ }^{\circ} \mathrm{C}\right)$ solution of ethyl acetoacetate $(117 \mu \mathrm{L}, 0.92 \mathrm{mmol})$ in anhydrous THF (2.8 $\mathrm{mL}$ ) was added $\mathrm{NaH}$ (60 \% dispersion in mineral oil, $37 \mathrm{mg}, 0.92 \mathrm{mmol}$ ) and the mixture was stirred for 15 minutes. $n$-BuLi in hexanes (2.5 M, $0.92 \mathrm{mmol}$ ) was then added dropwise and the mixture was stirred at $0{ }^{\circ} \mathrm{C}$ for a further 10 minutes. Cyclic sulfamidate 7c (100 mg, 0.46 mmol) was then added and the mixture was stirred at $50{ }^{\circ} \mathrm{C}$ for $16 \mathrm{~h}$. After cooling to r.t., aq. $5 \mathrm{M} \mathrm{HCl}(0.46 \mathrm{~mL})$ was added and the mixture was stirred at r.t. for $2 \mathrm{~h}$ prior to neutralisation with saturated aq. $\mathrm{NaHCO}_{3}$. The mixture was extracted with $\mathrm{CH}_{2} \mathrm{Cl}_{2}(3 \times 15 \mathrm{~mL})$ and the combined organic extracts were dried $\left(\mathrm{Na}_{2} \mathrm{SO}_{4}\right)$ and concentrated in vacuo. The residue was purified by FCC (hexanes- $\mathrm{Et}_{2} \mathrm{O}$ 5:1) to afford the title compound 8c (64 mg, 54 \%) as a colorless oil; $[\alpha]_{\mathrm{D}}{ }^{20}+144.6$ (c = 0.8, $\left.\mathrm{CHCl}_{3}\right) ; v_{\max } / \mathrm{cm}^{-1}$ (film) $2973(\mathrm{~m}), 1683$ (s), 1595 (s), 1404 (m), 1158 (s), 1126 (s), 1051 (s); $\delta_{\mathrm{H}}\left(400 \mathrm{MHz}, \mathrm{CDCl}_{3}\right)$ 1.20-1.26 (6H, m, C5-C $\underline{\mathrm{H}}_{3}$ and $\mathrm{CO}_{2} \mathrm{CH}_{2} \underline{\mathrm{C}}_{3}$ ), 2.76 (3H, s, $\mathrm{NC}_{3}$ ), 2.93 (1H, ddd, $J=8.5,7.5$ and 6.5, C4- $\left.\underline{\mathrm{H}}\right), 3.17$ (1H, dd, $J$ $=18.0$ and 7.5, C3- $\underline{\mathrm{H}}), 3.49$ (1H, dq, $J=6.5$ and 6.5, C5- $\underline{\mathrm{H}}), 3.65$ (1H, dd, $J=18.0$ and 8.5,

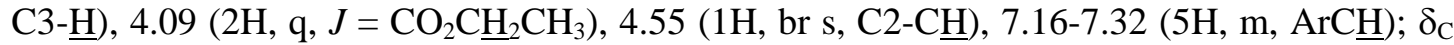
(100 MHz, $\left.\mathrm{CDCl}_{3}\right) 14.8$ and $18.4\left(\mathrm{C} 5-\underline{\mathrm{CH}_{3}}\right.$ and $\left.\left.\mathrm{CO}_{2} \mathrm{CH}_{2} \underline{\mathrm{C}} \mathrm{H}_{3}\right), 31.1\left(\mathrm{~N}_{\mathrm{CH}}\right)_{3}\right), 39.2(\underline{\mathrm{C}}-3), 49.0$ (ㅁ-4), $58.4\left(\mathrm{CO}_{2} \underline{\mathrm{CH}_{2}} \mathrm{CH}_{3}\right), 67.4(\underline{\mathrm{C}}-5), 78.5(\mathrm{C} 2-\underline{\mathrm{CH}}), 127.0,127.3$ and $128.8(\mathrm{Ar} \underline{\mathrm{CH}} \times 5)$, 142.4 (ArC), 164.5 and 169.4 ( $\underline{\mathrm{C}}-2$ and $\mathrm{CO}_{2} \mathrm{CH}_{2} \mathrm{CH}_{3}$ ); HRMS: $\left(\mathrm{ESI}^{+}\right.$) Found: $[\mathrm{M}+\mathrm{Na}]^{+}$ 282.1468, $\mathrm{C}_{16} \mathrm{H}_{21} \mathrm{NO}_{2} \mathrm{Na}$ requires 282.1465. Geometric assignment of this compound was based upon a diagnostic field gradient nOe observed between $\mathrm{NCH}_{3}$ and $\mathrm{C} 2$ '-C .

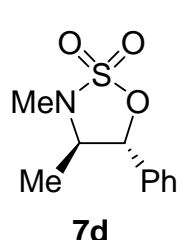

7d

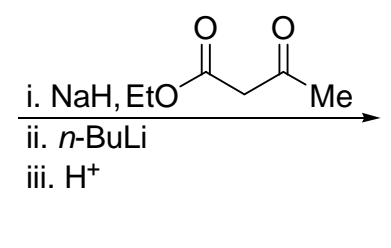

ii. $n$-BuL

80

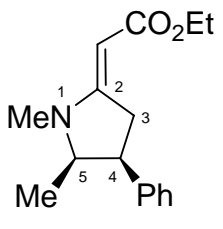

8d

[(4S,5R)-1,5-Dimethyl-4-phenylpyrrolidin-(2E)-ylidene]acetic acid ethyl ester (8d): To an ice-cooled $\left(0{ }^{\circ} \mathrm{C}\right)$ solution of ethyl acetoacetate $(117 \mu \mathrm{L}, 0.92 \mathrm{mmol})$ in anhydrous THF (2.8 $\mathrm{mL}$ ) was added $\mathrm{NaH}$ (60 \% dispersion in mineral oil, $37 \mathrm{mg}, 0.92 \mathrm{mmol}$ ) and the mixture was stirred for 15 minutes. $n$-BuLi in hexanes (2.5 M, $0.92 \mathrm{mmol})$ was then added dropwise and 
the mixture was stirred at $0{ }^{\circ} \mathrm{C}$ for a further 10 minutes. Cyclic sulfamidate $7 \mathbf{d}$ (100 mg, 0.46 mmol) was then added and the mixture was stirred at $50{ }^{\circ} \mathrm{C}$ for $48 \mathrm{~h}$. After cooling to r.t., aq. $5 \mathrm{M} \mathrm{HCl}(0.46 \mathrm{~mL})$ was added and the mixture was stirred at r.t. for $3 \mathrm{~h}$ prior to neutralisation with saturated aq. $\mathrm{NaHCO}_{3}$. The mixture was extracted with $\mathrm{CH}_{2} \mathrm{Cl}_{2}(3 \times 15 \mathrm{~mL})$ and concentrated in vacuo. The residue was dissolved in $\mathrm{Et}_{2} \mathrm{O}(20 \mathrm{~mL})$ and washed with aq. $1 \mathrm{M}$ $\mathrm{NaOH}(3 \times 20 \mathrm{~mL})$, dried $\left(\mathrm{Na}_{2} \mathrm{SO}_{4}\right)$ and concentrated in vacuo. The residue was purified by FCC (hexanes- $\mathrm{Et}_{2} \mathrm{O} 5: 1$ ) to afford the title compound $\mathbf{8 d}(45 \mathrm{mg}, 38 \%$ ) as a colorless oil. Continued elution afforded recovered $\mathbf{7 d}(12 \mathrm{mg}, 12 \%)$ as a colorless solid.

Data for 8d: $[\alpha]_{\mathrm{D}}{ }^{20}+225.0$ (c = 1.8, $\mathrm{CHCl}_{3}$ ); $v_{\max } / \mathrm{cm}^{-1}$ (film) 2974 (m), 1682 (s), 1596 (s), 1404 (m), 1149 (s), 1127 (s), 1053 (s); $\delta_{\mathrm{H}}\left(400 \mathrm{MHz}, \mathrm{CDCl}_{3}\right) 0.67$ (3H, d, $J=6.5, \mathrm{C} 5-\mathrm{C}_{3}$ ), 1.20 (3H, t, $J=7.0, \mathrm{CO}_{2} \mathrm{CH}_{2} \mathrm{C}_{3}$ ), 2.72 (3H, s, $\mathrm{NC}_{3}$ ), 3.20-3.30 (1H, m, C3- $\underline{\mathrm{H}}$ ), 3.49-3.58 (2H, m, C3- $\underline{\mathrm{H}}$ and $\mathrm{C} 4-\underline{\mathrm{H}}), 3.75(1 \mathrm{H}, \mathrm{dq}, J=6.5$ and 6.5, C5- $\underline{\mathrm{H}}), 4.00-4.09(2 \mathrm{H}, \mathrm{m}$,

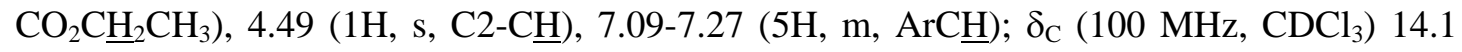

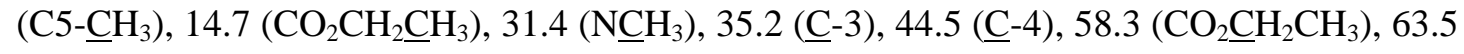
(ㅁ-5), $78.2(\mathrm{C} 2-\underline{\mathrm{CH}}), 126.8,128.2$ and $128.4(\mathrm{Ar} \underline{\mathrm{CH}} \times$ × 5), $139.0(\mathrm{Ar} \underline{\mathrm{C}}), 164.5$ and $169.4(\underline{\mathrm{C}}-2$ and $\mathrm{CO}_{2} \mathrm{CH}_{2} \mathrm{CH}_{3}$ ); HRMS: (ESI ${ }^{+}$) Found: $[\mathrm{M}+\mathrm{Na}]^{+}$282.1468, $\mathrm{C}_{16} \mathrm{H}_{21} \mathrm{NO}_{2} \mathrm{Na}$ requires 282.1465. Geometric assignment of this compound was based upon a diagnostic field gradient nOe observed between $\mathrm{NC}_{2} \mathrm{Ph}$ and $\mathrm{C}^{\prime}-\mathrm{C} \underline{\mathrm{H}}$.<smiles>O=S1(=O)OC(Cc2ccccc2)C[Sn]1</smiles>

$7 e$

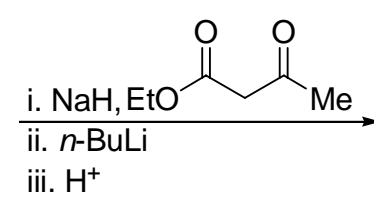

iii. $\mathrm{H}^{+}$

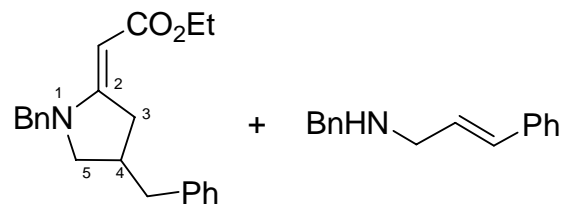

$8 e$

\section{[1,4-Dibenzylpyrrolidin-(2E)-ylidene]acetic acid ethyl ester (8e) and Benzyl-((E)-3-}

phenylallyl)amine: To an ice-cooled $\left(0{ }^{\circ} \mathrm{C}\right)$ solution of ethyl acetoacetate $(84 \mu \mathrm{L}, 0.66 \mathrm{mmol})$ in anhydrous THF (2 mL) was added $\mathrm{NaH}$ (60 \% dispersion in mineral oil, $26 \mathrm{mg}, 0.66$ mmol) and the mixture was stirred for 15 minutes. $n$-BuLi in hexanes (2.5 M, $0.66 \mathrm{mmol})$ was then added dropwise and the mixture was stirred at $0{ }^{\circ} \mathrm{C}$ for a further 10 minutes. Cyclic sulfamidate $7 \mathbf{e}(100 \mathrm{mg}, 0.33 \mathrm{mmol})$ was then added and the mixture was stirred at $50{ }^{\circ} \mathrm{C}$ for $16 \mathrm{~h}$. After cooling to r.t., aq. $5 \mathrm{M} \mathrm{HCl}(0.33 \mathrm{~mL})$ was added and the mixture was stirred at r.t. for $2 \mathrm{~h}$ prior to neutralisation with saturated aq. $\mathrm{NaHCO}_{3}$. The mixture was extracted with $\mathrm{CH}_{2} \mathrm{Cl}_{2}(3 \times 15 \mathrm{~mL})$ and the combined organic extracts were dried $\left(\mathrm{Na}_{2} \mathrm{SO}_{4}\right)$ and concentrated in vacuo. The residue was purified by FCC (hexanes-EtOAc 5:1) to afford pyrrolidine 8e (21 
mg, $19 \%$ ) as a colorless oil. Continued elution afforded $N$-benzyl cinnamylamine (22 mg, 30 $\%)$ as a colorless oil.

Data for 8e: $v_{\max } / \mathrm{cm}^{-1}$ (film) 2927 (m), 1734 (m), 1681 (s), 1594 (s), 1496 (m), 1454 (m), 1136 (s), $1058(\mathrm{~m}) ; \delta_{\mathrm{H}}\left(400 \mathrm{MHz}, \mathrm{CDCl}_{3}\right) 1.23$ (3H, t, $\left.J=7.5, \mathrm{CO}_{2} \mathrm{CH}_{2} \mathrm{C}_{3}\right), 2.55-2.65(2 \mathrm{H}$, m, C4- $\underline{\mathrm{H}}$ and $\left.\mathrm{C} 4-\mathrm{CH}_{2} \mathrm{Ph}\right), 2.73-2.83\left(1 \mathrm{H}, \mathrm{m}, \mathrm{C} 4-\mathrm{C}_{2} \mathrm{Ph}\right), 2.96(1 \mathrm{H}, \mathrm{dd}, J=17.5$ and 6.0, C3$\underline{\mathrm{H}}), 3.07$ (1H, dd, $J=10.0$ and 5.5, C5- $\underline{\mathrm{H}}), 3.32$ (1H, dd, $J=10.0$ and 7.0, C5- $\underline{\mathrm{H}}), 3.45$ (1H, dd, $J=17.5$ and 7.5, C3-프), $4.08\left(2 \mathrm{H}, \mathrm{q}, J=7.5, \mathrm{CO}_{2} \underline{\mathrm{C}}_{2} \mathrm{CH}_{3}\right), 4.28(1 \mathrm{H}, \mathrm{d}, J=16.5$,

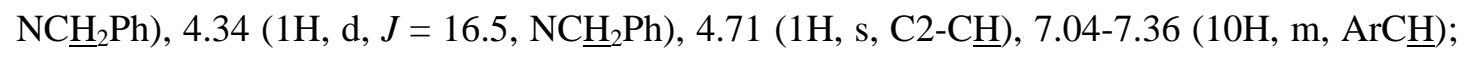

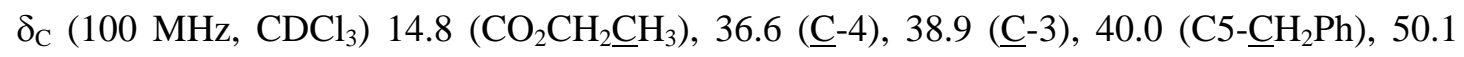
$\left(\mathrm{NCH}_{2} \mathrm{Ph}\right), 57.0$ (ㄷ-5), $58.5\left(\mathrm{CO}_{2} \underline{\mathrm{CH}}_{2} \mathrm{CH}_{3}\right), 78.8(\mathrm{C} 2-\underline{\mathrm{CH}}), 126.4,127.3,127.6,128.6$ and 128.8 (2 signals) $(\operatorname{Ar} \underline{C} H \times 10), 136.2$ and $139.9(\operatorname{Ar} \underline{C} \times 2), 164.8$ and $169.6(\underline{\mathrm{C}}-2$ and $\mathrm{CO}_{2} \mathrm{CH}_{2} \mathrm{CH}_{3}$ ); HRMS: (ESI ${ }^{+}$) Found: $[\mathrm{M}+\mathrm{Na}]^{+}$358.1782, $\mathrm{C}_{22} \mathrm{H}_{25} \mathrm{NO}_{2} \mathrm{Na}$ requires 358.1778. Geometric assignment of this compound was based upon a diagnostic field gradient nOe observed between $\mathrm{NC}_{2} \mathrm{Ph}$ and $\mathrm{C} 2 '-\underline{\mathrm{CH}}$.

Data for $N$-benzyl cinnamylamine: $\delta_{\mathrm{H}}\left(400 \mathrm{MHz}, \mathrm{CDCl}_{3}\right) 1.63(1 \mathrm{H}, \mathrm{br} \mathrm{s}, \mathrm{N} \underline{\mathrm{H}}), 3.42(2 \mathrm{H}, \mathrm{d}, J$ $=6.0, \mathrm{C} 1-\underline{\mathrm{H}}), 3.82\left(2 \mathrm{H}, \mathrm{s}, \mathrm{NC}_{2} \mathrm{Ph}\right), 6.30(1 \mathrm{H}, \mathrm{d} \mathrm{t}, J=16.0$ and 6.0, C2-프), $6.53(1 \mathrm{H}, \mathrm{d}, J=$ 16.0, C3- $\underline{\mathrm{H}}), 7.18-7.39$ (10H, m, $\mathrm{ArC} \underline{\mathrm{H}}) ; \mathrm{m} / \mathrm{z}\left(\mathrm{CI}^{+}\right) 224$ ([M+H] $\left.]^{+}, 100 \%\right)$. The spectroscopic properties of this compound were consistent with the data available in the literature. ${ }^{1}$

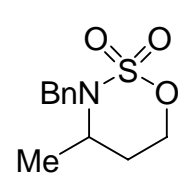

$7 f$

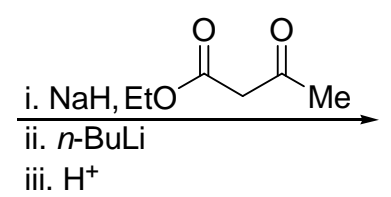

iii. $\mathrm{H}^{+}$

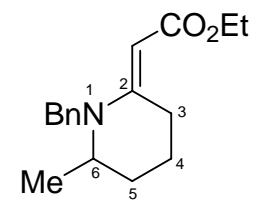

$8 f$

[1-Benzyl-6-methylpiperidin-(2E)-ylidene]acetic acid ethyl ester (8f): To an ice-cooled (0 $\left.{ }^{\circ} \mathrm{C}\right)$ solution of ethyl acetoacetate $(54 \mu \mathrm{L}, 0.42 \mathrm{mmol})$ in anhydrous THF $(1.5 \mathrm{~mL})$ was added $\mathrm{NaH}$ (60 \% dispersion in mineral oil, $17 \mathrm{mg}, 0.42 \mathrm{mmol}$ ) and the mixture was stirred for 15 minutes. $n$-BuLi in hexanes (2.5 M, $0.42 \mathrm{mmol})$ was then added dropwise and the mixture was stirred at $0{ }^{\circ} \mathrm{C}$ for a further 20 minutes. Cyclic sulfamidate $7 \mathbf{f}$ (50 mg, $0.21 \mathrm{mmol}$ ) was then added and the mixture was stirred at $50{ }^{\circ} \mathrm{C}$ for $72 \mathrm{~h}$. After cooling to r.t., aq. $5 \mathrm{M} \mathrm{HCl}$ $(0.21 \mathrm{~mL})$ was added and the mixture was stirred at r.t. for $3 \mathrm{~h}$ prior to neutralisation with saturated aq. $\mathrm{NaHCO}_{3}$. The mixture was extracted with $\mathrm{CH}_{2} \mathrm{Cl}_{2}(3 \times 15 \mathrm{~mL})$ and the combined organic extracts were dried $\left(\mathrm{Na}_{2} \mathrm{SO}_{4}\right)$ and concentrated in vacuo. The residue was 
purified by FCC (hexanes-EtOAc 10:1) to afford the title compound $8 \mathbf{8}$ (26 $\mathrm{mg}, 45 \%$ ) as a colorless oil. Continued elution afforded recovered $\mathbf{7 f}(8 \mathrm{mg}, 15 \%)$ as a colorless solid.

Data for 8f: $v_{\max } / \mathrm{cm}^{-1}$ (film) 2939 (m), 1679 (m), 1558 (s), 1135 (s), 1099 (m), 1054 (m); $\delta_{\mathrm{H}}$ (400 MHz, $\mathrm{CDCl}_{3}$ ) 1.15-1.21 (6H, m, C6- $\underline{\mathrm{H}}_{3}$ and $\mathrm{CO}_{2} \mathrm{CH}_{2} \mathrm{C}_{3}$ ), 1.57-1.73 (2H, m, C4- $\underline{\mathrm{H}}$ ), 1.73-1.87 (1H, m, C5- $\underline{\mathrm{H}}), 1.91-2.00(1 \mathrm{H}, \mathrm{m}, \mathrm{C} 5-\underline{\mathrm{H}}), 3.13$ (1H, ddd, $J=18.0,9.0$ and 6.0, C3$\underline{\mathrm{H}}), 3.26$ (1H, ddd, $J=18.0,6.0$ and 5.5, C3- $\underline{\mathrm{H}}), 3.43-3.51(1 \mathrm{H}, \mathrm{m}, \mathrm{C} 6-\underline{\mathrm{H}}), 3.95-4.05$ (2H, m, $\left.\mathrm{CO}_{2} \mathrm{C}_{2} \mathrm{CH}_{3}\right), 4.32\left(1 \mathrm{H}, \mathrm{d}, J=17.0, \mathrm{NC}_{2} \mathrm{Ph}\right), 4.51\left(1 \mathrm{H}, \mathrm{d}, J=17.0, \mathrm{NC}_{2} \mathrm{Ph}\right), 4.57(1 \mathrm{H}, \mathrm{s}$,

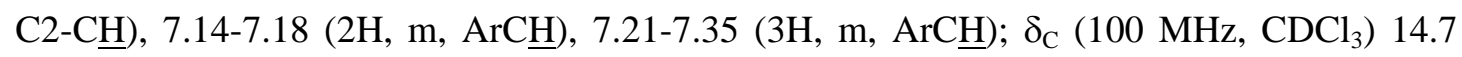

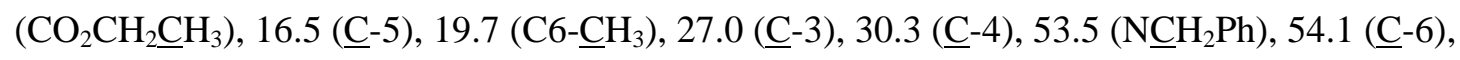
$58.2\left(\mathrm{CO}_{2} \underline{\mathrm{CH}}_{2} \mathrm{CH}_{3}\right), 84.2(\mathrm{C} 2-\underline{\mathrm{CH}}), 126.5,127.0$ and $128.7(\mathrm{Ar} \underline{\mathrm{C}} \mathrm{H} \times 5), 136.8(\mathrm{Ar} \underline{\mathrm{C}}), 162.4$ and 169.1 ( $\underline{\mathrm{C}}-2$ and $\mathrm{CO}_{2} \mathrm{CH}_{2} \mathrm{CH}_{3}$ ); HRMS: (ESI ${ }^{+}$) Found: [M+Na] ${ }^{+}$296.1628, $\mathrm{C}_{17} \mathrm{H}_{23} \mathrm{NO}_{2} \mathrm{Na}$ requires 296.1621. Geometric assignment of this compound was based upon a diagnostic field gradient nOe observed between $\mathrm{NC}_{2} 2 \mathrm{Ph}$ and $\mathrm{C} 2$ '- $\underline{\mathrm{H}} \underline{\mathrm{H}}$.
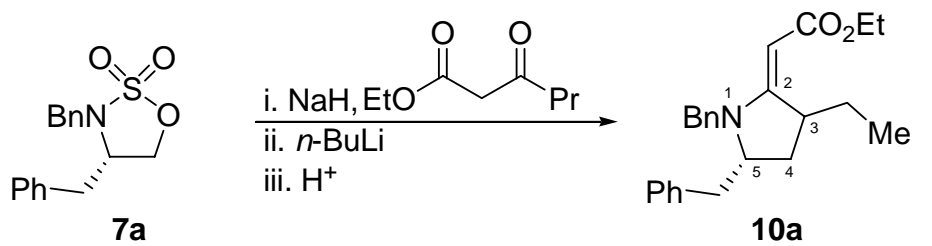

[(R)-1,5-Dibenzyl-3-ethylpyrrolidin-(2E)-ylidene]acetic acid ethyl ester (10a): To an icecooled $\left(0{ }^{\circ} \mathrm{C}\right)$ solution of ethyl 3-oxohexanoate $(106 \mu \mathrm{L}, 0.66 \mathrm{mmol})$ in anhydrous THF (2 $\mathrm{mL}$ ) was added $\mathrm{NaH}$ (60 \% dispersion in mineral oil, $26 \mathrm{mg}, 0.66 \mathrm{mmol}$ ) and the mixture was stirred for 10 minutes. $n$-BuLi in hexanes $(2.5 \mathrm{M}, 0.66 \mathrm{mmol})$ was then added dropwise and the mixture was stirred at $0{ }^{\circ} \mathrm{C}$ for a further 15 minutes. Cyclic sulfamidate $7 \mathbf{a}$ (100 mg, 0.33 mmol) was then added and the mixture was stirred at r.t. for 22 h. Aq. $5 \mathrm{M} \mathrm{HCl}(0.33 \mathrm{~mL})$ was added and the mixture was stirred at r.t. for $3 \mathrm{~h}$ prior to neutralisation with saturated aq. $\mathrm{NaHCO}_{3}$. The mixture was extracted with $\mathrm{CH}_{2} \mathrm{Cl}_{2}(3 \times 15 \mathrm{~mL})$ and the combined organic extracts were dried $\left(\mathrm{Na}_{2} \mathrm{SO}_{4}\right)$ and concentrated in vacuo. The residue was purified by FCC (hexanes-EtOAc 8:1) to afford the title compound 10a (81 mg, 68 \%, 3:2 d.r. A:B) as a colorless oil; $v_{\max } / \mathrm{cm}^{-1}$ (film) 2964 (m), 1682 (m), 1589 (s), 1578 (s), 1453 (m), 1131 (s), 1060 (m); $\delta_{\mathrm{H}}\left(400 \mathrm{MHz}, \mathrm{CDCl}_{3}\right) 0.92$ (3H, t, $J=7.5, \mathrm{C}^{-}-\mathrm{CH}_{2} \mathrm{CH}_{3}$ of $\left.A\right), 1.09$ (3H, t, $J=7.5$, C3- $\mathrm{CH}_{2} \mathrm{CH}_{3}$ of $B$ ), 1.20-1.33 (6H, m, $\mathrm{CO}_{2} \mathrm{CH}_{2} \mathrm{CH}_{3}$ of $A$ and $\left.B\right), 1.36-1.48(1 \mathrm{H}, \mathrm{m}, \mathrm{C} 3-$ $\mathrm{C}_{2} \mathrm{CH}_{3}$ of $B$ ), 1.62-1.84 (5H, m, C3- $\underline{\mathrm{H}}_{2} \mathrm{CH}_{3}$ of $A$ and $B$ and $\mathrm{C} 4-\underline{\mathrm{H}} \times 3$ of $\mathrm{A}$ and $B$ ), 2.02 (1H, ddd, $J=13.0,10.0$ and 10.0, C4- $\underline{\mathrm{H}}$ of $B$ ), 2.09-2.21 (1H, m, C3- $\underline{\mathrm{H}}_{2} \mathrm{CH}_{3}$ of $\left.B\right), 2.36(1 \mathrm{H}$, dd, $J=12.5$ and 10.0, C5-C $\underline{\mathrm{H}}_{2} \mathrm{Ph}$ of A), 2.59 (1H, dd, $J=13.0$ and 10.0, C5-C $\underline{\mathrm{H}}_{2} \mathrm{Ph}$ of $B$ ), 3.08 
(1H, dd, $J=13.5$ and 4.5, C5- $\underline{\mathrm{C}}_{2} \mathrm{Ph}$ of $B$ ), 3.14 (1H, dd, $J=12.5$ and 4.5, C5- $\underline{\mathrm{H}}_{2} \mathrm{Ph}$ of $A$ ), 3.58-3.66 (2H, m, C3- $\underline{\mathrm{H}}$ of $A$ and $B), 3.71-3.83(2 \mathrm{H}, \mathrm{m}, \mathrm{C} 5-\underline{\mathrm{H}}$ of $A$ and $B), 4.01-4.15(4 \mathrm{H}, \mathrm{m}$,

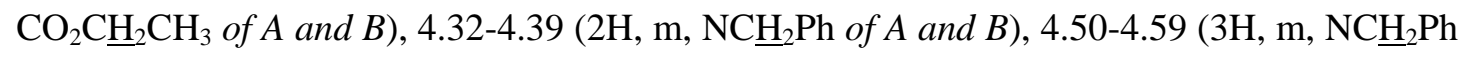
of $A$ and $B$ and C2-Cㅂ of $B), 4.64(1 \mathrm{H}, \mathrm{s}, \mathrm{C} 2-\mathrm{C} \underline{\mathrm{H}}$ of $A), 7.01-7.37(20 \mathrm{H}, \mathrm{m}, \mathrm{ArC} \underline{\mathrm{H}}) ; \delta_{\mathrm{C}}(100$ $\left.\mathrm{MHz}, \mathrm{CDCl}_{3}\right) 12.5\left(\mathrm{C} 2-\mathrm{CH}_{2} \mathrm{CH}_{3}\right.$ of $\left.\mathrm{A}\right), 12.8\left(\mathrm{C} 2-\mathrm{CH}_{2} \mathrm{CH}_{3}\right.$ of $\left.B\right), 14.8\left(\mathrm{CO}_{2} \mathrm{CH}_{2} \mathrm{CH}_{3}\right.$ of $A$ and B), $26.3\left(\mathrm{C} 3-\mathrm{CH}_{2} \mathrm{CH}_{3}\right.$ of $A$ ), $28.9\left(\mathrm{C} 3-\underline{\mathrm{CH}_{2}} \mathrm{CH}_{3}\right.$ of $B$ ), 33.0 (ㄷ-4 of $A$ and $\left.B\right), 41.0\left(\mathrm{C}^{-}-\underline{\mathrm{CH}}_{2} \mathrm{Ph}\right.$

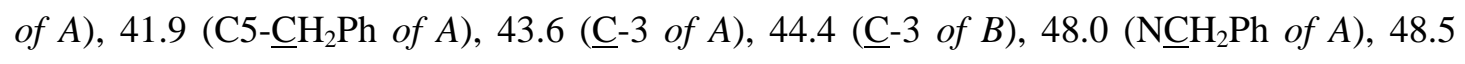
( $\mathrm{NCH}_{2} \mathrm{Ph}$ of $B$ ), 58.5 (2 signals) $\left(\mathrm{CO}_{2} \mathrm{CH}_{2} \mathrm{CH}_{3}\right.$ of $A$ and $B$ ), 62.7 ( $\underline{\mathrm{C}}-5$ of $A$ ), 65.1 ( $\underline{\mathrm{C}}-5$ of $B$ ), 78.6 (C2-ㅡㅐ of B), 79.1 (C2-대 of A), 126.6, 126.7, 126.8, 126.9, 127.4 (2 signals), 128.6,

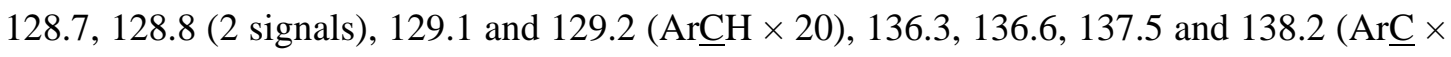
4), 168.7, 168.9, 170.0 and 170.8 ( $\underline{\mathrm{C}}-2$ and $\underline{\mathrm{CO}_{2}} \mathrm{CH}_{2} \mathrm{CH}_{3}$ of $A$ and B); HRMS: (ESI ${ }^{+}$) Found: $[\mathrm{M}+\mathrm{Na}]^{+}$386.2096, $\mathrm{C}_{24} \mathrm{H}_{29} \mathrm{NO}_{2} \mathrm{Na}$ requires 386.2091.
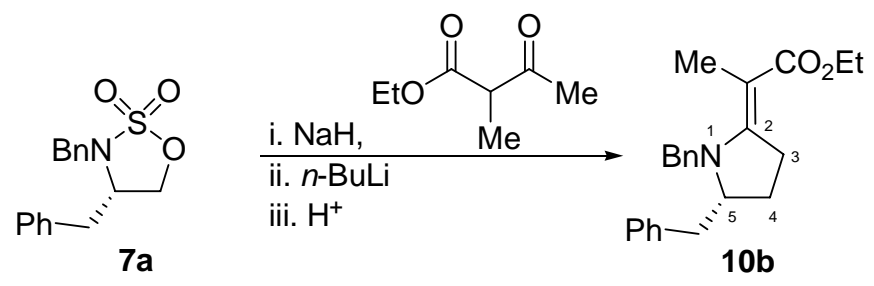

2-[(R)-1,5-Dibenzylpyrrolidin-(2E)-ylidene]propionic acid ethyl ester (10b): To an icecooled $\left(0{ }^{\circ} \mathrm{C}\right)$ solution of ethyl 2-methylacetoacetate ( $\left.93 \mu \mathrm{L}, 0.66 \mathrm{mmol}\right)$ in anhydrous THF (2 $\mathrm{mL}$ ) was added $\mathrm{NaH}$ (60\% dispersion in mineral oil, $26 \mathrm{mg}, 0.66 \mathrm{mmol}$ ) and the mixture was stirred for 10 minutes. $n$-BuLi in hexanes (1.6 M, $0.66 \mathrm{mmol})$ was then added dropwise and the mixture was stirred at $0{ }^{\circ} \mathrm{C}$ for a further 15 minutes. Cyclic sulfamidate $7 \mathbf{a}$ (100 mg, 0.33 mmol) was then added and the mixture was stirred at r.t. for 60 h. Aq. $5 \mathrm{M} \mathrm{HCl}(0.33 \mathrm{~mL})$ was added and the mixture was stirred at r.t. for $3 \mathrm{~h}$ prior to neutralisation with saturated aq. $\mathrm{NaHCO}_{3}$. The mixture was extracted with $\mathrm{CH}_{2} \mathrm{Cl}_{2}(3 \times 15 \mathrm{~mL})$ and the combined organic extracts were dried $\left(\mathrm{Na}_{2} \mathrm{SO}_{4}\right)$ and concentrated in vacuo. The residue was purified by FCC (hexanes-EtOAc 3:1) to afford the title compound 10b (65 mg, 58 \%, 11:1 E:Z) as a colorless oil; $[\alpha]_{\mathrm{D}}^{20}+144.4$ (c = 0.4, $\left.\mathrm{CHCl}_{3}\right) ; v_{\max } / \mathrm{cm}^{-1}$ (film) 2932 (m), 1678 (s), 1572 (s), 1453 (m), 1264 (s), 1101 (s); $\delta_{\mathrm{H}}\left(400 \mathrm{MHz}, \mathrm{CDCl}_{3}\right.$ ) (data for major diastereomer only) 1.26 (3H, t, $J=$ 7.5, $\left.\mathrm{CO}_{2} \mathrm{CH}_{2} \underline{\mathrm{C}}_{3}\right), 1.51-1.60(1 \mathrm{H}, \mathrm{m}, \mathrm{C} 4-\underline{\mathrm{H}}), 1.76-1.85$ (1H, m, C4- $\left.\underline{\mathrm{H}}\right), 1.96$ (3H, s, C2$\left.\mathrm{CC}_{3}{ }_{3}\right), 2.48$ (1H, dd, $J=13.0$ and 9.0, C5- $\left.\underline{\mathrm{H}}_{2} \mathrm{Ph}\right), 2.90-3.00\left(2 \mathrm{H}, \mathrm{m}, \mathrm{C} 5-\mathrm{C}_{2} \mathrm{Ph}\right.$ and $\left.\mathrm{C} 3-\underline{\mathrm{H}}\right)$, 3.11 (1H, ddd, $J=17.0$, 8.5 and 5.0, C3-프), 3.49-3.57 (1H, m, C5- $\underline{\mathrm{H}}), 4.12$ (2H, q, $J=7.5$, $\mathrm{CO}_{2} \underline{\mathrm{C}}_{2} \mathrm{CH}_{3}$ ), $4.33\left(1 \mathrm{H}, \mathrm{d}, J=16.0, \mathrm{NC}_{2} \mathrm{Ph}\right), 4.87$ (1H, d, $J=16.0, \mathrm{NC}_{2} \mathrm{Ph}$ ), 7.03-7.07 $(2 \mathrm{H}, \mathrm{m}, \mathrm{ArC} \underline{\mathrm{H}}), 7.17-7.35$ (8H, m, $\mathrm{ArC} \underline{\mathrm{H}}) ; \delta_{\mathrm{C}}\left(100 \mathrm{MHz}, \mathrm{CDCl}_{3}\right)$ (data for major

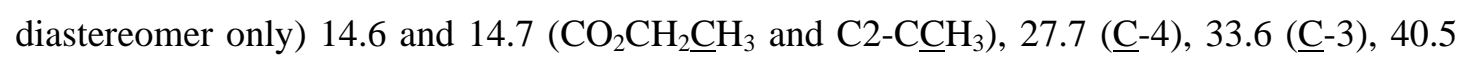


(C5- $\left.\underline{\mathrm{CH}}_{2} \mathrm{Ph}\right), 52.2\left(\mathrm{NCH}_{2} \mathrm{Ph}\right), 59.1\left(\mathrm{CO}_{2} \mathrm{CH}_{2} \mathrm{CH}_{3}\right), 65.0$ (ㄷ-5), 90.8 (C2-) $), 126.3,127.2$, 127.3, 128.4, 128.6 and $129.1(\mathrm{Ar} \underline{\mathrm{C}} \mathrm{H} \times 10), 138.2$ and $138.6(\mathrm{Ar} \underline{\mathrm{C}} \times 2), 164.0$ and $170.6(\underline{\mathrm{C}}-2$ and $\left.\mathrm{CO}_{2} \mathrm{CH}_{2} \mathrm{CH}_{3}\right) ; \mathrm{m} / \mathrm{z}\left(\mathrm{CI}^{+}\right) 350\left([\mathrm{M}+\mathrm{H}]^{+}, 100 \%\right.$; HRMS: $\left(\mathrm{CI}^{+}\right)$Found: $[\mathrm{M}+\mathrm{H}]^{+}$350.2110, $\mathrm{C}_{23} \mathrm{H}_{28} \mathrm{NO}_{2}$ requires 350.2120. Geometric assignment of this compound was based upon a diagnostic field gradient nOe observed between $\mathrm{NC}_{2} \mathrm{Ph}$ and $\mathrm{C}^{\prime}-\mathrm{CC} \underline{H}_{3}$.

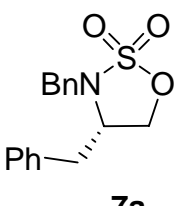

$7 \mathbf{a}$

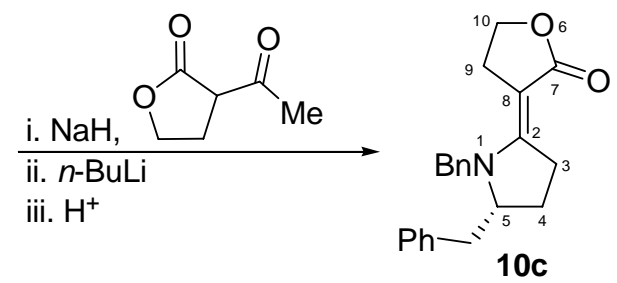

10c

3-[(R)-1,5-Dibenzylpyrrolidin-(2E)-ylidene]dihydrofuran-2-one (10c): To an ice-cooled (0 $\left.{ }^{\circ} \mathrm{C}\right)$ solution of acetyl butyrolactone $(71 \mu \mathrm{L}, 0.66 \mathrm{mmol})$ in anhydrous THF $(2 \mathrm{~mL})$ was added $\mathrm{NaH}$ (60 \% dispersion in mineral oil, $26 \mathrm{mg}, 0.66 \mathrm{mmol}$ ) and the mixture was stirred for 10 minutes. $n$-BuLi in hexanes $(1.6 \mathrm{M}, 0.66 \mathrm{mmol})$ was then added dropwise and the mixture was stirred at $0{ }^{\circ} \mathrm{C}$ for a further 15 minutes. Cyclic sulfamidate $7 \mathbf{a}(100 \mathrm{mg}, 0.33 \mathrm{mmol})$ was then added and the mixture was stirred at r.t. for $45 \mathrm{~h}$. Aq. $5 \mathrm{M} \mathrm{HCl}(0.33 \mathrm{~mL})$ was added and the mixture was stirred at r.t. for $3 \mathrm{~h}$ prior to neutralisation with saturated aq. $\mathrm{NaHCO}_{3}$. The mixture was extracted with $\mathrm{CH}_{2} \mathrm{Cl}_{2}(3 \times 15 \mathrm{~mL})$ and the organic extracts were concentrated in vacuo. The residue was dissolved in $\mathrm{Et}_{2} \mathrm{O}(20 \mathrm{~mL})$ and washed with aq. $1 \mathrm{M} \mathrm{NaOH}(3 \times 20$ $\mathrm{mL}$ ), dried $\left(\mathrm{Na}_{2} \mathrm{SO}_{4}\right)$ and concentrated in vacuo. The residue was purified by FCC (EtOAchexanes 1:1) to afford the title compound 10c (51 mg, $46 \%,>9: 1 \mathrm{E:Z}$ ) as a colorless oil. Continued elution afforded recovered cyclic sulfamidate $7 \mathbf{a}$ (10 mg, $10 \%$ ).

Data for 10c: $[\alpha]_{\mathrm{D}}{ }^{20}-23.5$ (c = 0.3, $\left.\mathrm{CHCl}_{3}\right) ; v_{\max } / \mathrm{cm}^{-1}$ (film) 1709 (s), 1591 (s), $1452(\mathrm{~m})$,

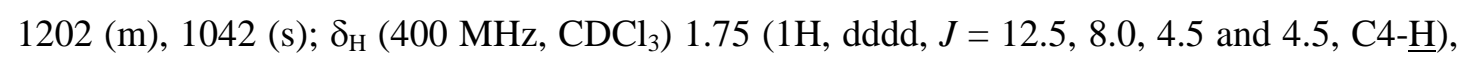
1.91 ( $1 \mathrm{H}$, dddd, $J=12.5,9.0,8.0$ and 1.5, C4- $\underline{\mathrm{H}}$ ), 2.56 (1H, dd, $J=13.0$ and 9.0, C5- $\underline{\mathrm{H}}_{2} \mathrm{Ph}$ ), 2.91-3.17 (4H, m, C9- $\underline{\mathrm{H}} \times$ 2, C3- $\underline{\mathrm{H}}$ and $\left.\mathrm{C} 5-\mathrm{C}_{2} \mathrm{Ph}\right)$, 3.36 (1H, ddddd, $J=18.0$, 9.0, 5.5, 1.5

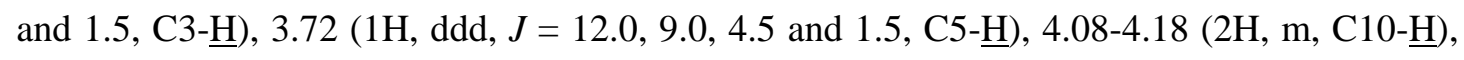
4.41 (1H, d, $J=17.0, \mathrm{NC}_{2} \mathrm{Ph}$ ), 4.93 (1H, d, $\left.J=17.0, \mathrm{NC}_{2} \mathrm{Ph}\right), 7.05-7.40$ (10H, m, ArC$)$;

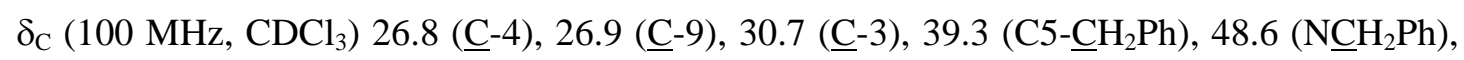

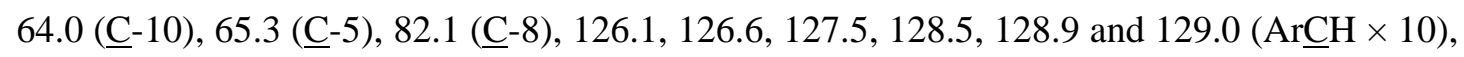
137.5 and $138.0(\operatorname{Ar} \underline{C} \times 2), 160.5(\underline{C}-2), 174.6(\underline{C}-7)$; HRMS: $\left(\mathrm{ESI}^{+}\right)$Found: $[\mathrm{M}+\mathrm{H}]^{+}$ 334.1803, $\mathrm{C}_{22} \mathrm{H}_{24} \mathrm{NO}_{2}$ requires 334.1802. Geometric assignment of this compound was based upon analogy with $\mathbf{1 0 b}$. 

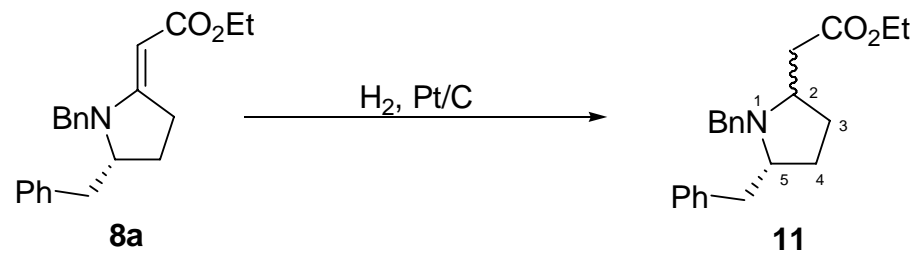

((R)-1,5-Dibenzylpyrrolidin-2-yl)acetic acid ethyl ester (11): Alkylidene pyrrolidine 8a (200 mg, $0.57 \mathrm{mmol}$ ), and 5 \% Pt/C (55 mg, $25 \mathrm{wt} \%$ ) were dissolved in EtOAc (2 mL) and the mixture was sealed inside a hydrogenation bomb. The vessel was then purged with $\mathrm{H}_{2}$ (6 purge cycles at a pressure of $3.5 \mathrm{bar}$ ) and the mixture was stirred at r.t. for $21 \mathrm{~h}$. The vessel was then depressurised, the mixture was filtered through Celite ${ }^{\circledR}$ and the residue was washed with $\mathrm{CH}_{2} \mathrm{Cl}_{2}(10 \mathrm{~mL})$. The filtrate was concentrated in vacuo to afford a yellow oil which was purified by FCC (hexanes-EtOAc 3:1) to yield amine 11 (178 mg, 89 \%, 5:2 d.r. A (cis):B(trans)) as a colorless oil; $v_{\max } / \mathrm{cm}^{-1}$ (film) 1729 (s), 1494 (m), 1453 (m), 1175 (m), $1120(\mathrm{~m}) ; \delta_{\mathrm{H}}\left(400 \mathrm{MHz}, \mathrm{CDCl}_{3}\right)$ 1.19-1.24 (6H, m, $\mathrm{CO}_{2} \mathrm{CH}_{2} \mathrm{CH}_{3}$ of $A$ and $\left.B\right), 1.45-1.78(5 \mathrm{H}$, $\mathrm{m}, \mathrm{C} 3-\underline{\mathrm{H}} \times 2$ of A, C4- $\underline{\mathrm{H}}$ of A and C3- $\underline{\mathrm{H}} \times 2$ of B), 1.82-1.92 (2H, m, C4- $\underline{\mathrm{H}}$ of A and B), 2.02-

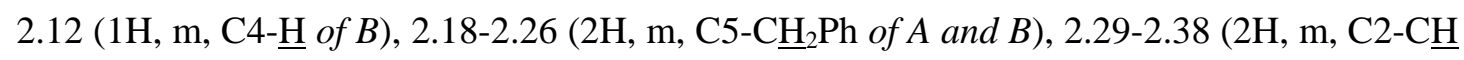
of $A$ and $B), 2.46\left(1 \mathrm{H}, \mathrm{dd}, J=15.0\right.$ and 4.5, C5- $\mathrm{CH}_{2} \mathrm{Ph}$ of $\left.A\right), 2.59(1 \mathrm{H}, \mathrm{dd}, J=14.5$ and 4.0,

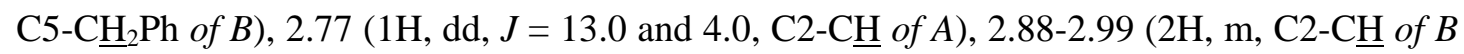

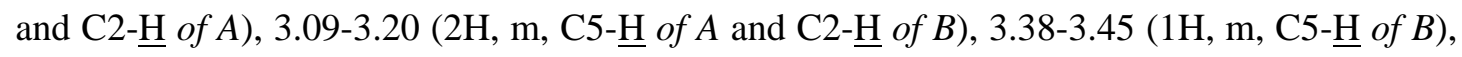
$3.75\left(1 \mathrm{H}, \mathrm{d}, J=14.0, \mathrm{NC}_{2} \mathrm{Ph}\right.$ of $\left.B\right), 3.83\left(2 \mathrm{H}, \mathrm{s}, \mathrm{NC}_{2} \mathrm{Ph}\right.$ of $\left.A\right), 3.98(1 \mathrm{H}, \mathrm{d}, J=14.0$,

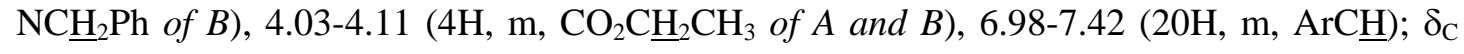
(100 MHz, $\left.\mathrm{CDCl}_{3}\right) 14.2\left(\mathrm{CO}_{2} \mathrm{CH}_{2} \underline{\mathrm{CH}_{3}}\right.$ of $A$ and $B$ ), 27.0, 28.6, 29.0 and 29.6 (드-3 and $\underline{\mathrm{C}}-4$ of

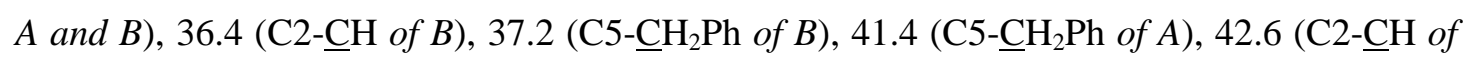
A), $51.8\left(\mathrm{NCH}_{2} \mathrm{Ph}\right.$ of $\left.B\right), 57.6$ (드-5 of $\left.B\right), 57.8\left(\mathrm{NCH}_{2} \mathrm{Ph}\right.$ of $\left.A\right), 60.1$ and $60.2\left(\mathrm{CO}_{2} \mathrm{CH}_{2} \mathrm{CH}_{3}\right.$ of $A$ and B), 62.0 (2 signals) (C-5 of $A$ and $\underline{\mathrm{C}}-2$ of $B$ ), 66.6 ( $\underline{\mathrm{C}}-2$ of $A$ ), 125.7, 125.8, 126.8 (2 signals), 128.1 (3 signals), 128.2, 128.3, 129.0, 129.1 and $129.2(\mathrm{Ar} \underline{\mathrm{CH}} \times 20), 139.8,139.9$, 140.0 and $140.2(\mathrm{Ar} \underline{C} \times 4), 172.3$ and $172.6\left(\underline{C O}_{2} \mathrm{CH}_{2} \mathrm{CH}_{3}\right)$; HRMS: $\left(\mathrm{ESI}^{+}\right)$Found: $[\mathrm{M}+\mathrm{H}]^{+}$ 338.2109, $\mathrm{C}_{22} \mathrm{H}_{28} \mathrm{NO}_{2}$ requires 338.2115. Geometric assignment of diastereomer $B$ was based upon a diagnostic field gradient nOe observed between $\mathrm{C} 5-\underline{\mathrm{H}}$ and $\mathrm{C} 2-\mathrm{C} \underline{\mathrm{H}}$ which is indicative of a trans arrangement of ring substituents. On this basis the MAJOR diastereomer $A$ was assigned as cis. 


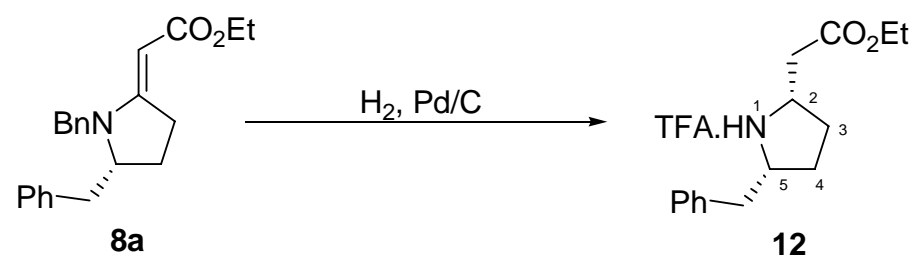

((R)-5-Benzylpyrrolidin-2-yl)acetic acid ethyl ester trifluoroacetate (12): Alkylidene pyrrolidine 8a (137 mg, $0.39 \mathrm{mmol}$ ), and 10 \% Pd/C (78 mg, $55 \mathrm{wt} \%$ ) were dissolved in AcOH $(1 \mathrm{~mL})$ and TFA $(0.25 \mathrm{~mL})$ and the mixture was sealed inside a hydrogenation bomb. The vessel was then purged with $\mathrm{H}_{2}$ (6 purge cycles at a pressure of 8.5 bar) and the mixture was stirred at r.t. for $48 \mathrm{~h}$. The vessel was then depressurised, the mixture was filtered through Celite ${ }^{\circledR}$ and the residue was washed sequentially with $\mathrm{MeOH}(15 \mathrm{~mL})$ and $\mathrm{CH}_{2} \mathrm{Cl}_{2}(20 \mathrm{~mL})$. The filtrate was concentrated in vacuo to afford amine 12 (135 mg, 100 \%, ca. 9:1 d.r., major diastereomer shown) as an amorphous, pale yellow solid; m.p. 88-90 ${ }^{\circ} \mathrm{C}(\mathrm{MeOH}) ; v_{\max } / \mathrm{cm}^{-1}$ (film) 1733 (m), 1670 (s), 1199 (s), 1178 (s), 1131 (s), 1028 (m); $\delta_{\text {H }}(400 \mathrm{MHz}, \mathrm{MeOD)}$ (data for major diastereomer only) 1.27 (3H, t, $J=7.0, \mathrm{CO}_{2} \mathrm{CH}_{2} \mathrm{C}_{3}$ ), 1.75-1.88 (2H, m, C4- $\underline{\mathrm{H}}$ ), 2.05-2.14 (1H, m, C2- $\left.\underline{\mathrm{H}}_{2}\right)$, 2.24-2.33 (1H, m, C2- $\left.\underline{\mathrm{C}}_{2}\right)$, 2.80-2.89 (2H, m, C3- $\left.\underline{\mathrm{H}}\right), 2.96(1 \mathrm{H}$, dd, $J=13.5$ and 8.5, C5- $\left.\underline{H}_{2} \mathrm{Ph}\right), 3.14\left(1 \mathrm{H}, \mathrm{dd}, J=13.5\right.$ and 6.5, $\left.\mathrm{C} 5-\underline{\mathrm{C}}_{2} \mathrm{Ph}\right), 3.79-3.95(2 \mathrm{H}$, m, C2- $\underline{\mathrm{H}}$ and $\mathrm{C} 5-\underline{\mathrm{H}}), 4.20$ (2H, q, $\left.J=7.0, \mathrm{CO}_{2} \mathrm{CH}_{2} \mathrm{CH}_{3}\right), 7.25-7.37$ (5H, m, ArC$)$, a signal attributable to $\underline{\mathrm{N}}_{2}$ was not observed; $\delta_{\mathrm{C}}(100 \mathrm{MHz}, \mathrm{MeOD})$ (data for major diastereomer only) $14.4\left(\mathrm{CO}_{2} \mathrm{CH}_{2} \underline{\mathrm{C}} \mathrm{H}_{3}\right), 29.5$ and 29.6 ( $\underline{\mathrm{C}}-4$ and $\left.\mathrm{C} 2-\underline{\mathrm{CH}_{2}}\right), 37.4(\underline{\mathrm{C}}-3), 40.0\left(\mathrm{C}^{-}-\underline{\mathrm{CH}}_{2} \mathrm{Ph}\right)$, 57.6 and 63.4 (ㄷ-2 and $\underline{\mathrm{C}}-5), 62.3\left(\mathrm{CO}_{2} \mathrm{CH}_{2} \mathrm{CH}_{3}\right), 128.4$ and 130.0 (2 signals) (ArCH $\times 5$ ), 137.8 (ArC), $171.7\left(\underline{C O}_{2} \mathrm{CH}_{2} \mathrm{CH}_{3}\right)$, a signal attributable to the TFA counterion was not observed; m/z (CI $) 248\left([\mathrm{M}+\mathrm{H}]^{+}, 100 \%\right)$; HRMS: $\left(\mathrm{CI}^{+}\right)$Found: $[\mathrm{M}+\mathrm{H}]^{+}$248.1644, $\mathrm{C}_{15} \mathrm{H}_{22} \mathrm{NO}_{2}$ requires 248.1651 .

\section{(C) References relevant to Supporting Information}

1. J. Blid, P. Brandt and P. Somfai, J. Org. Chem. 2004, 69, 3043-3049. 
(D) Copies of ${ }^{1} \mathrm{H}$ and ${ }^{13} \mathrm{C}$ NMR spectra
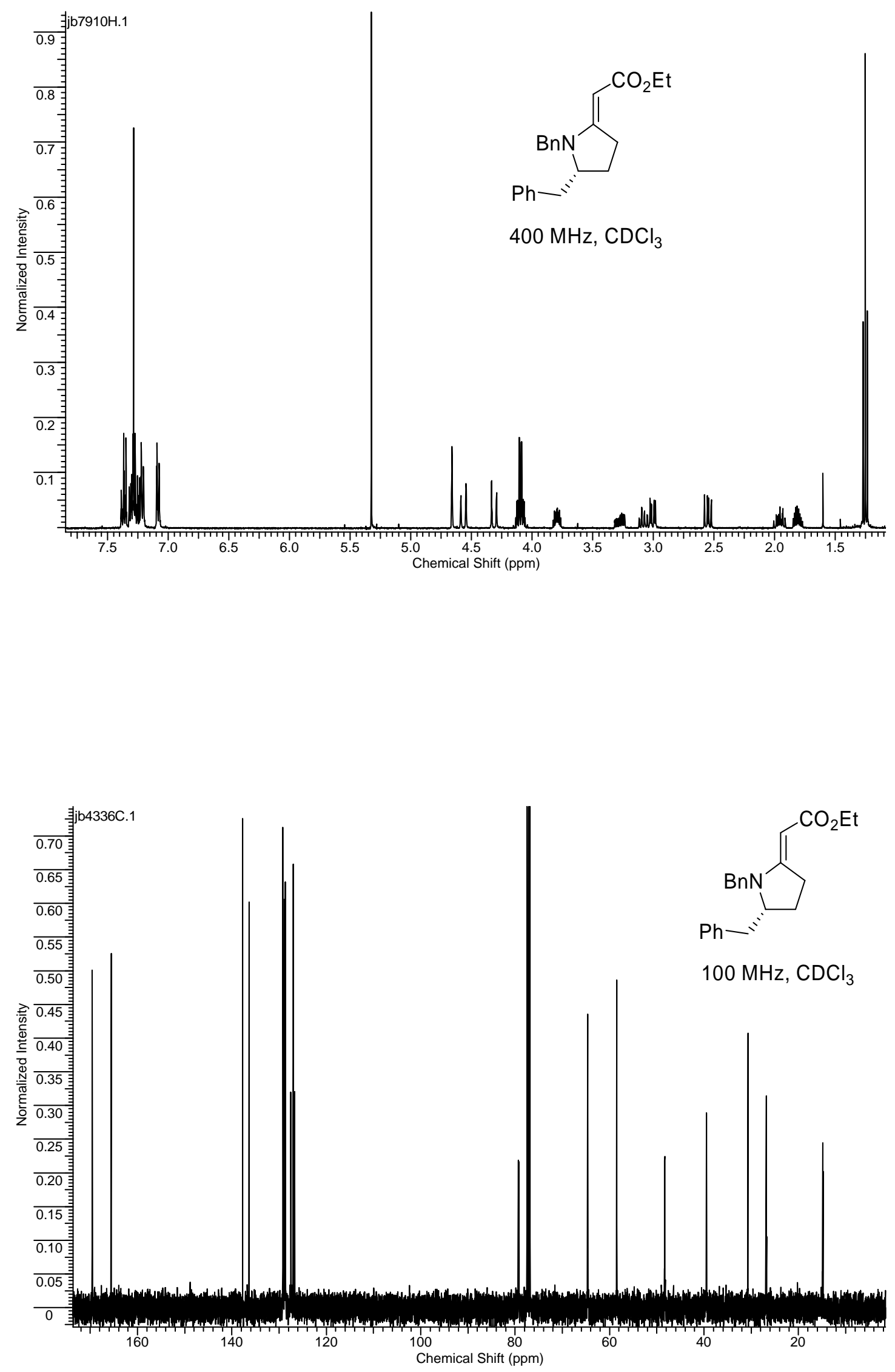

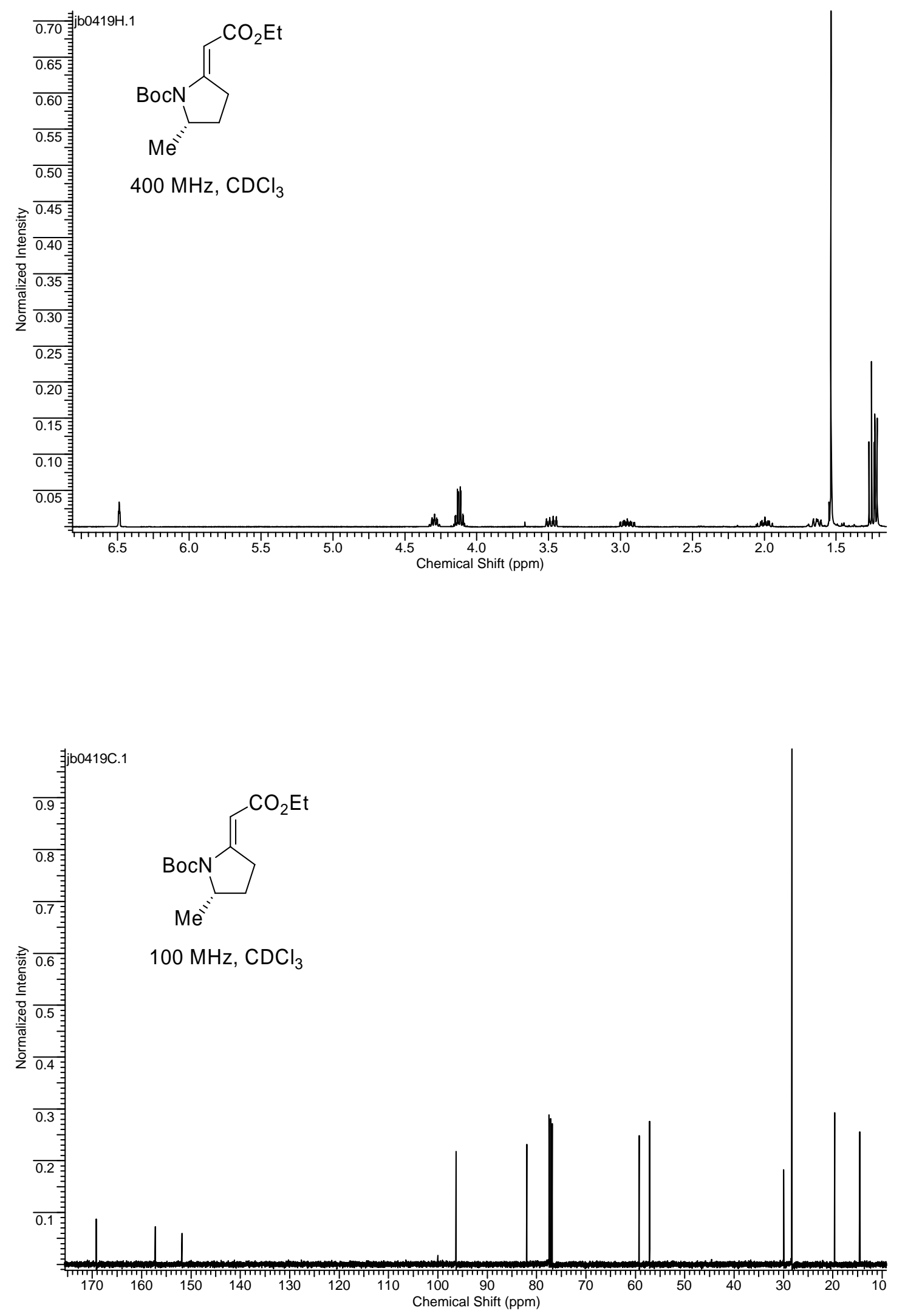

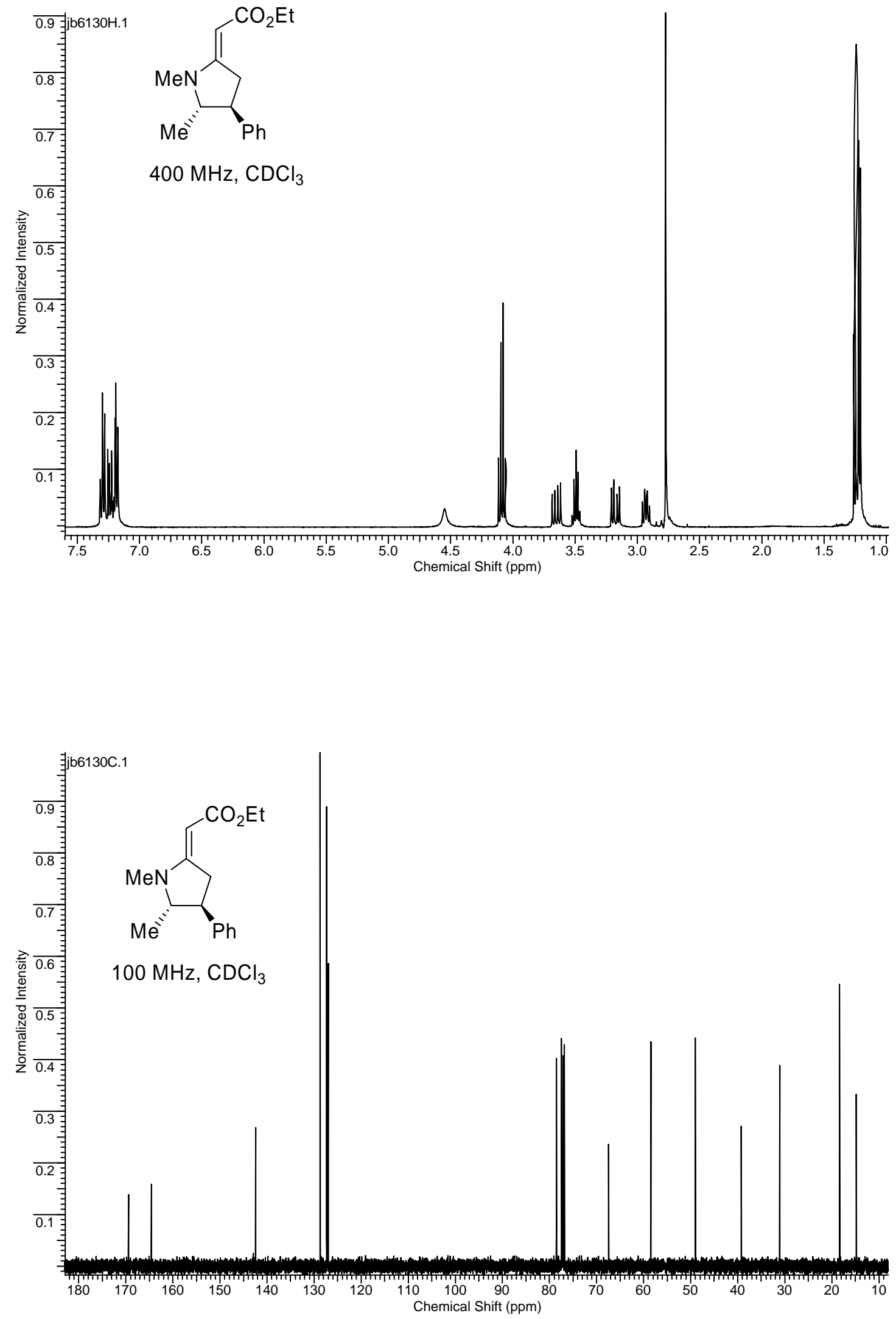

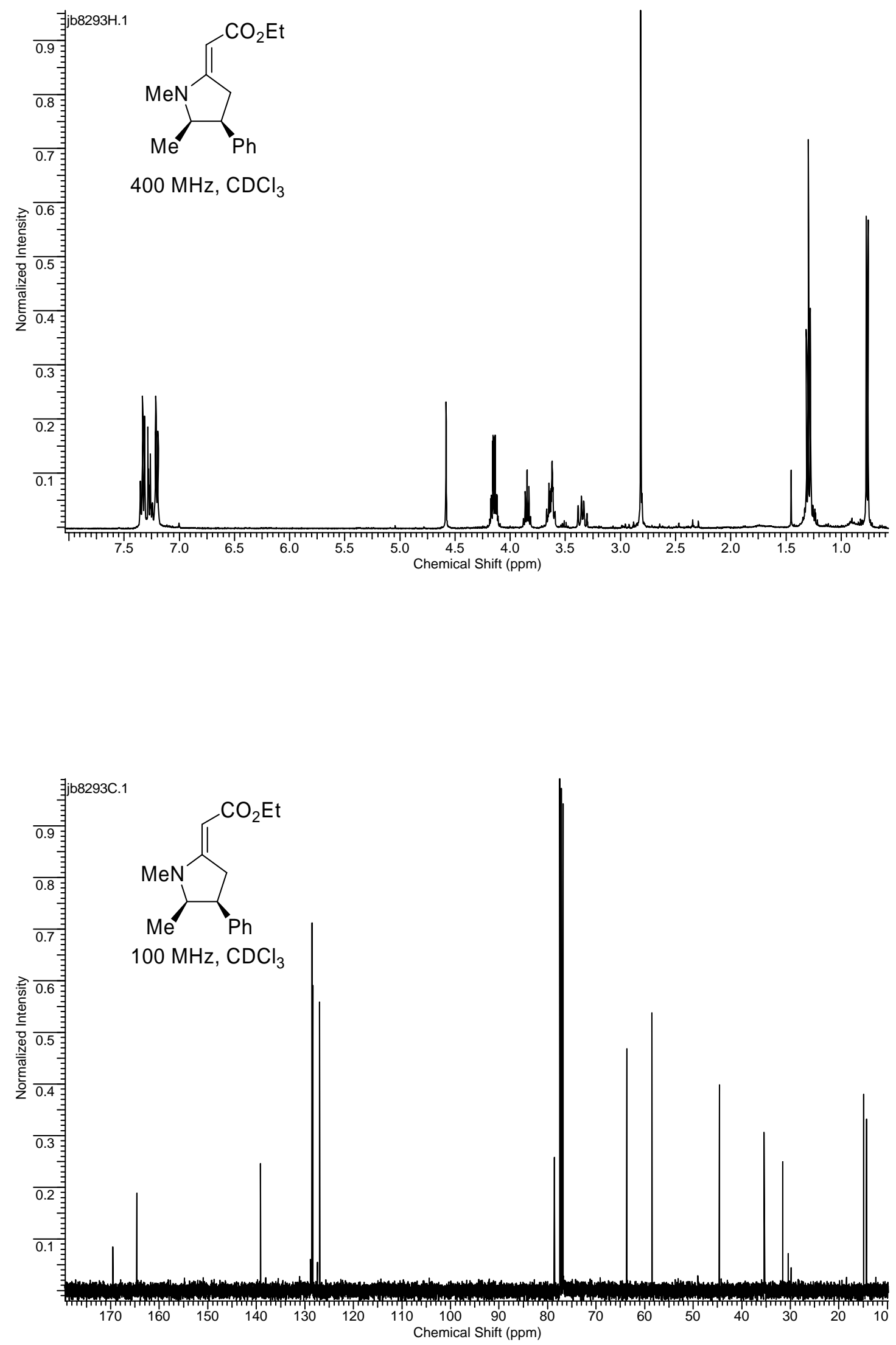

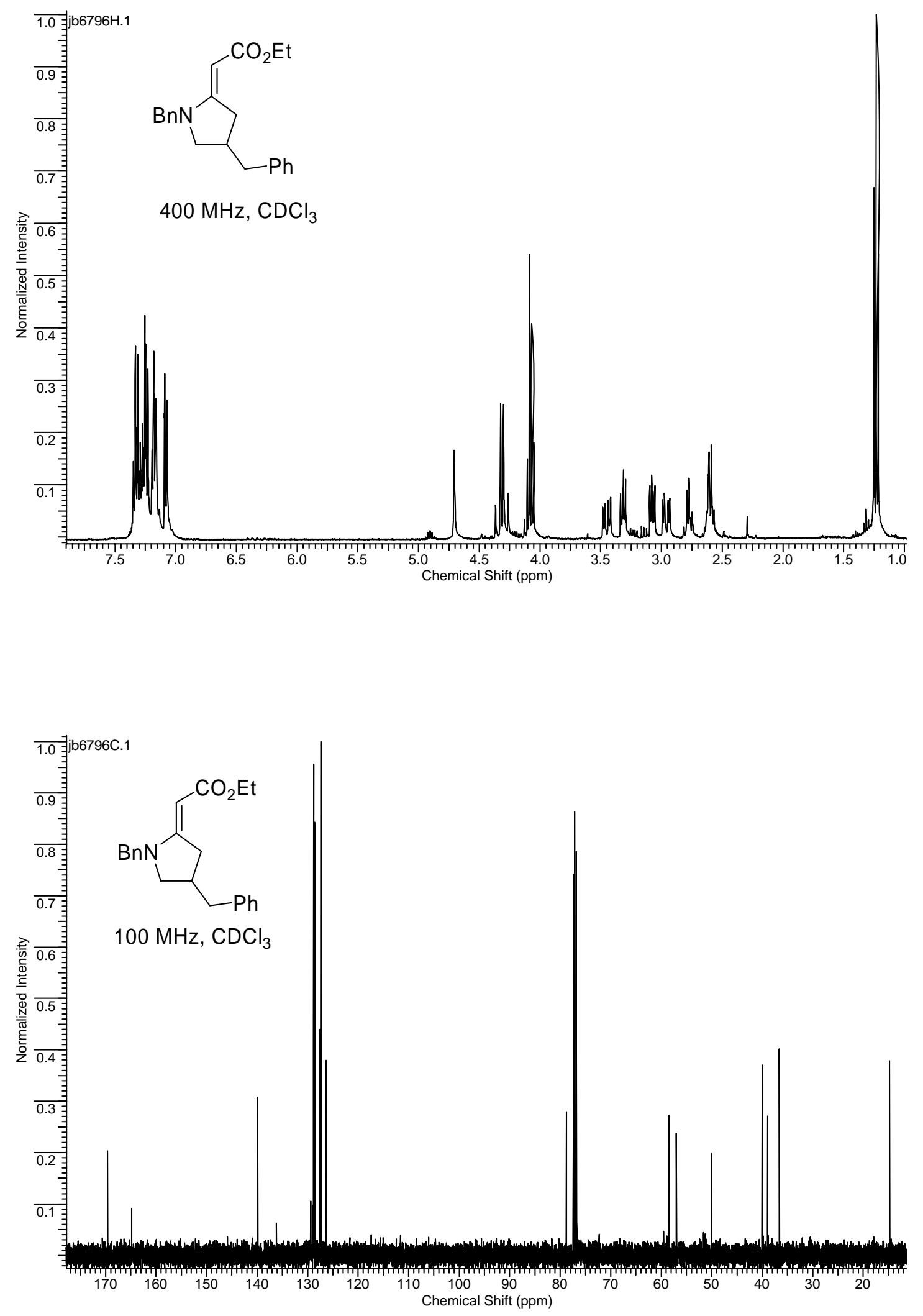

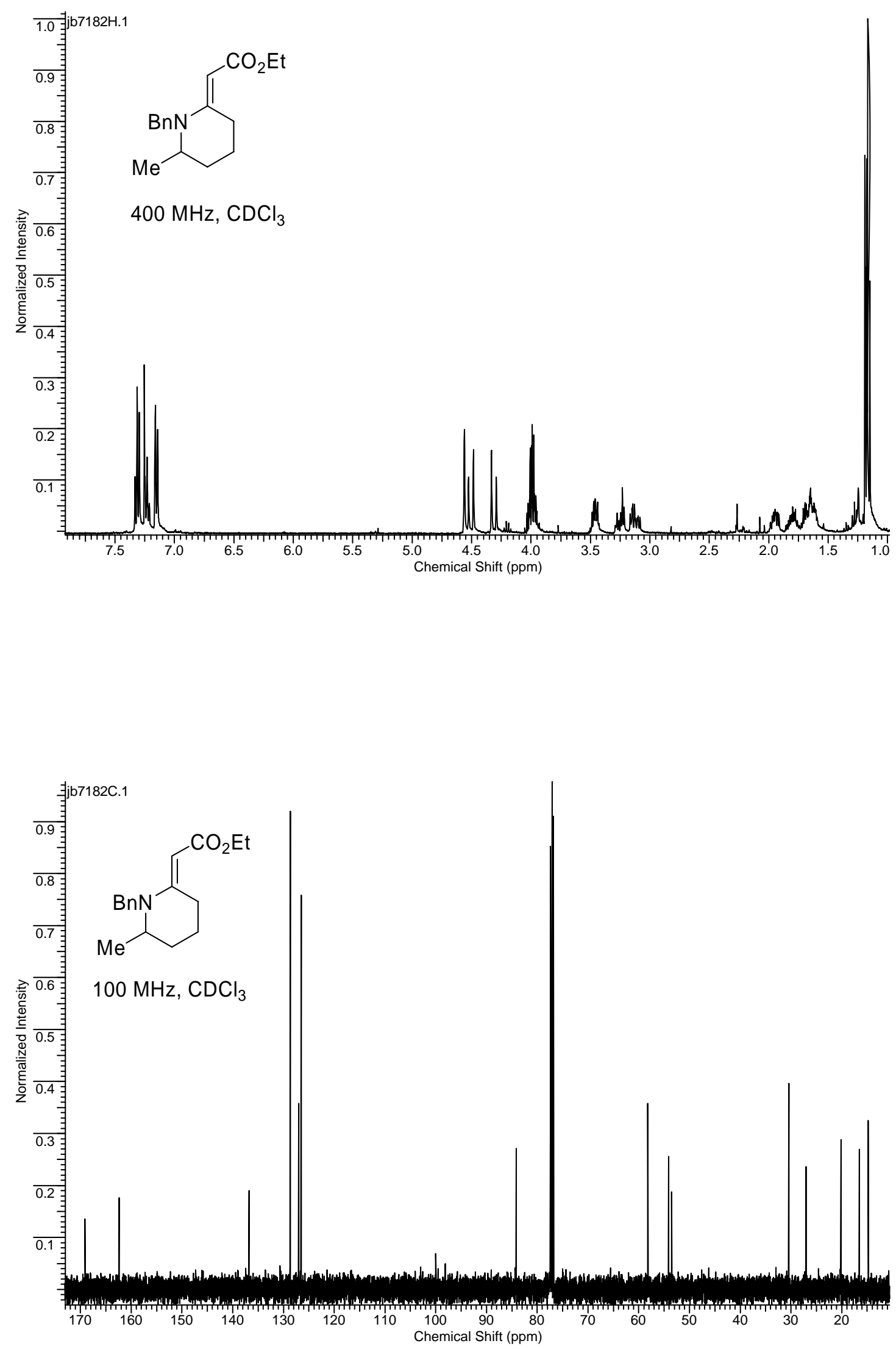

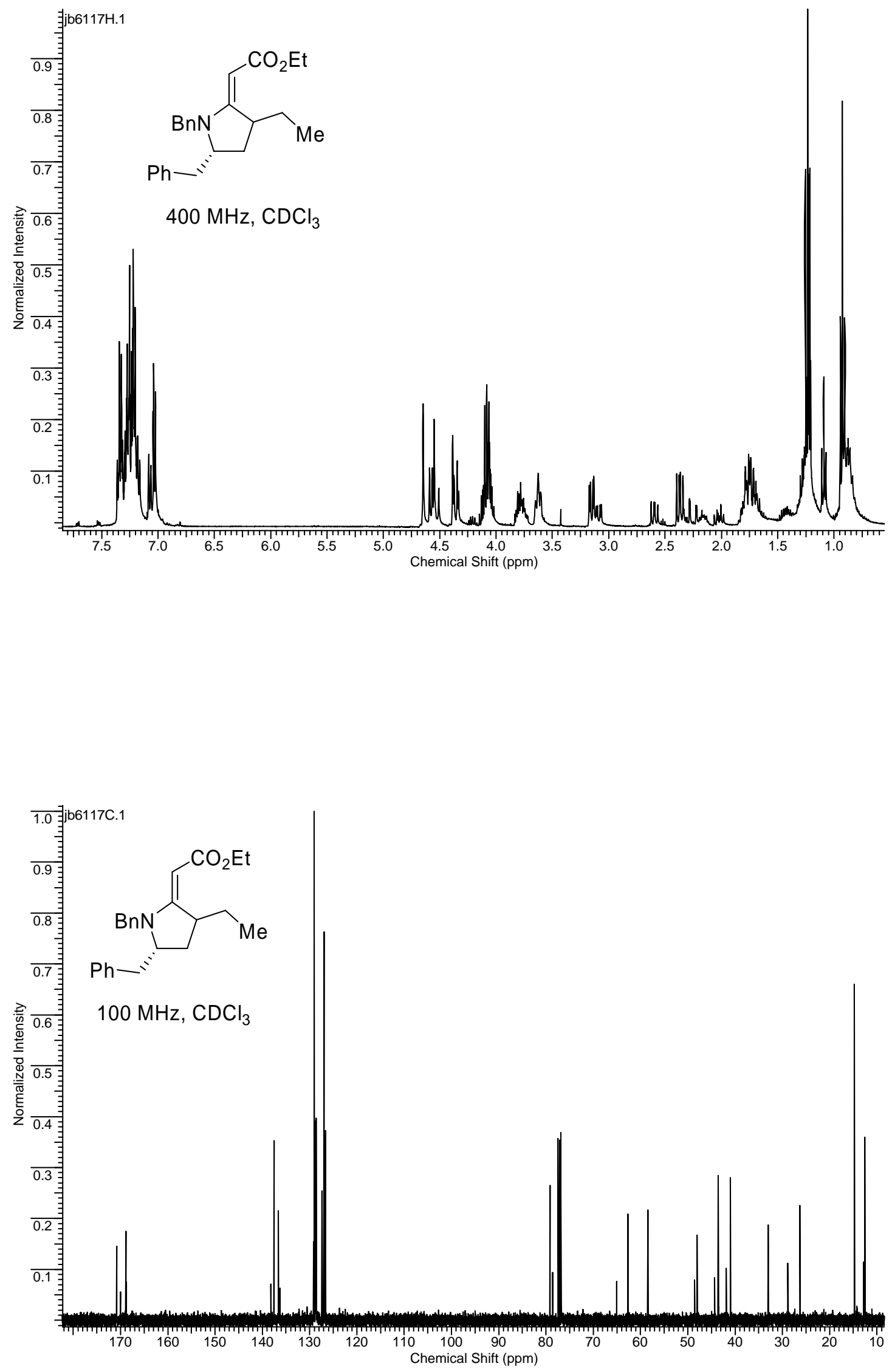

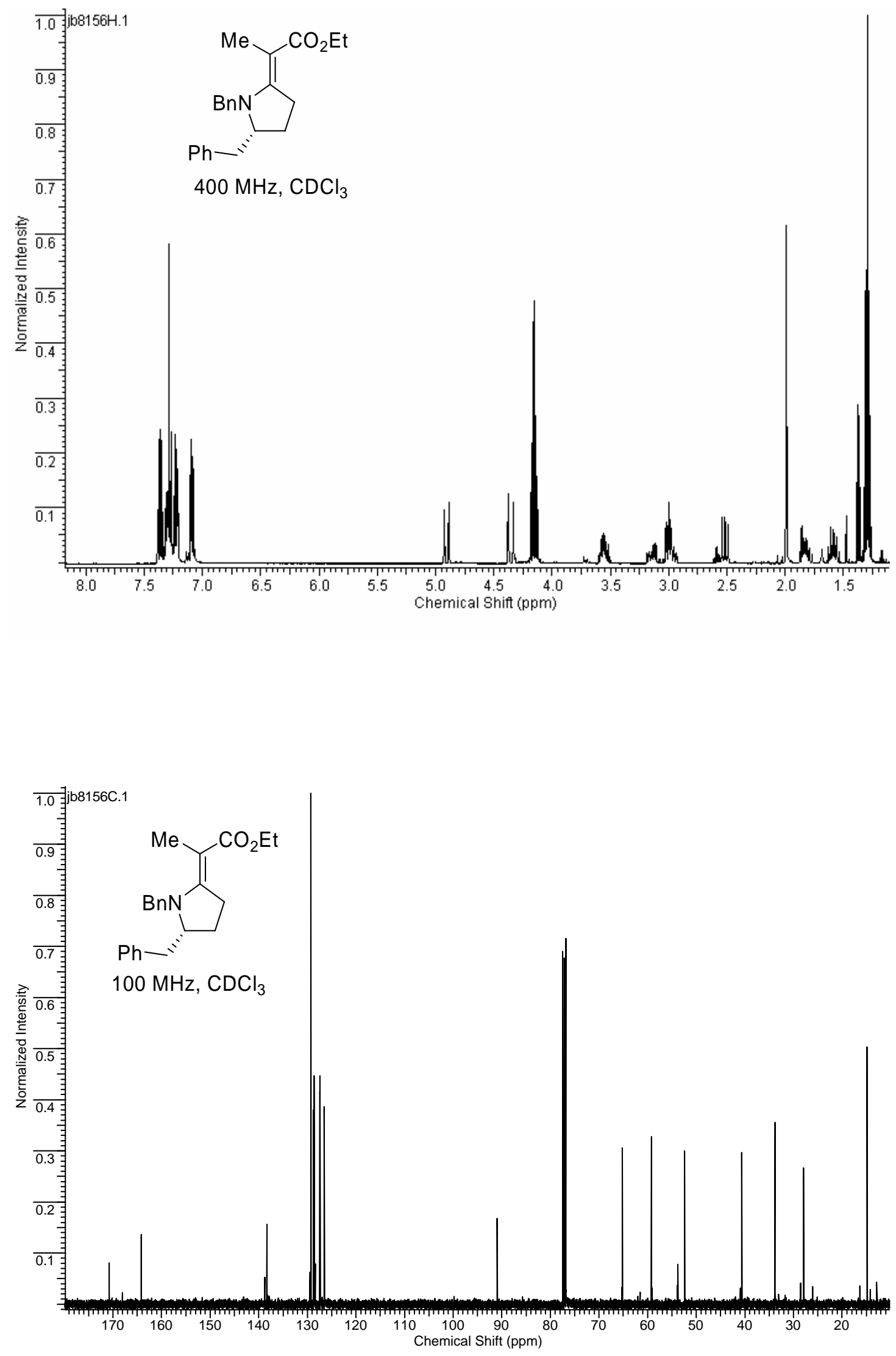

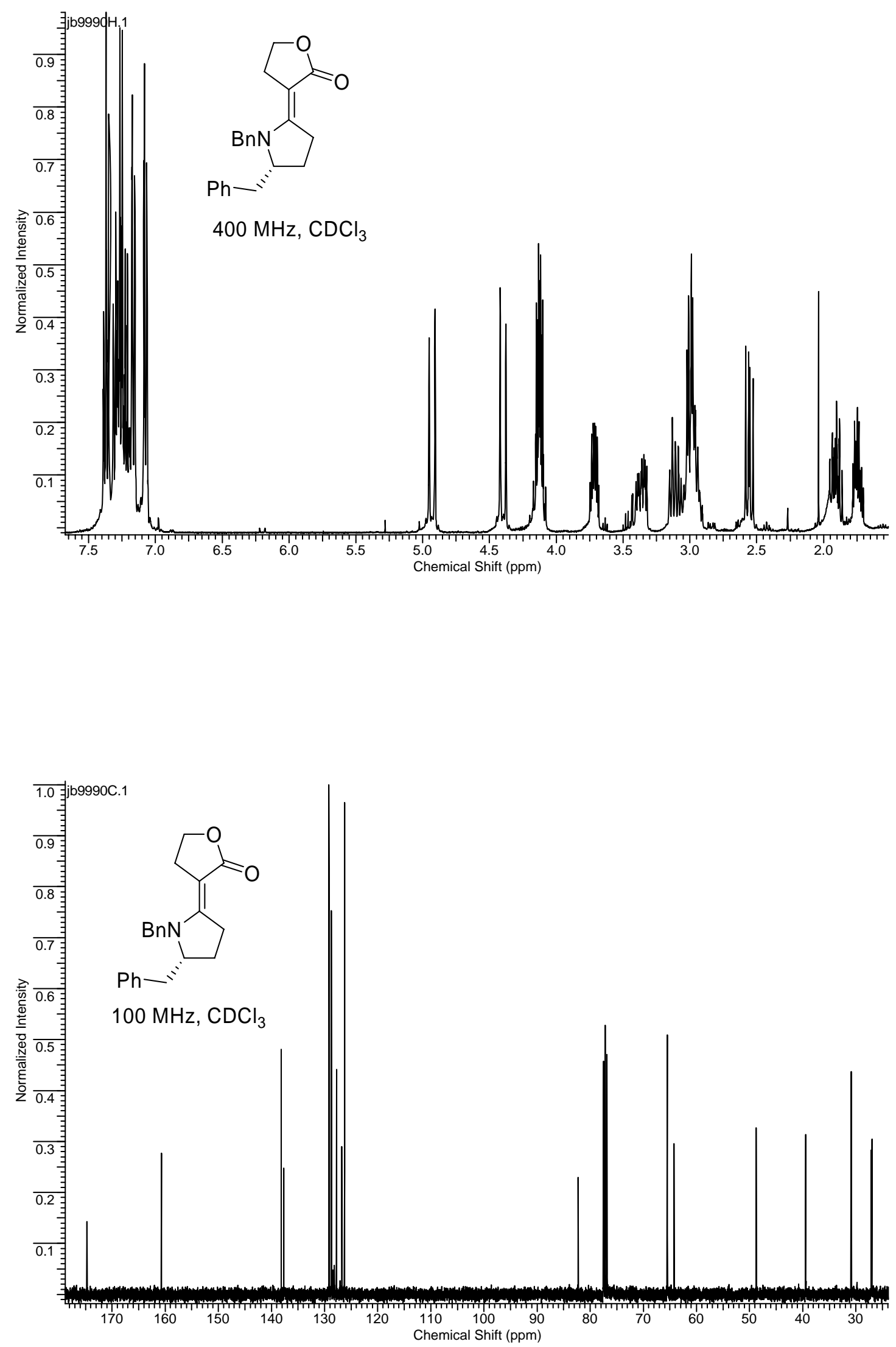

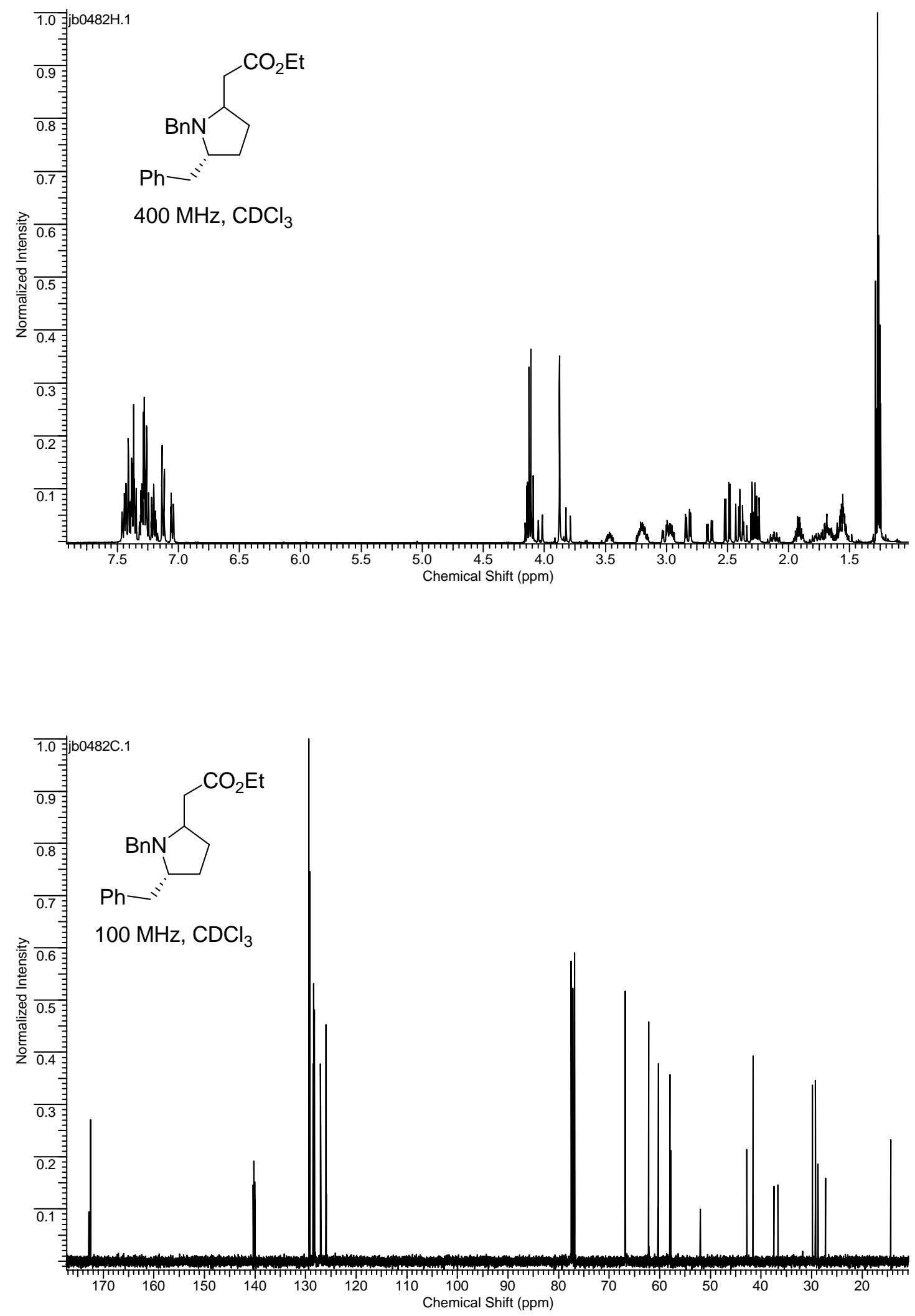

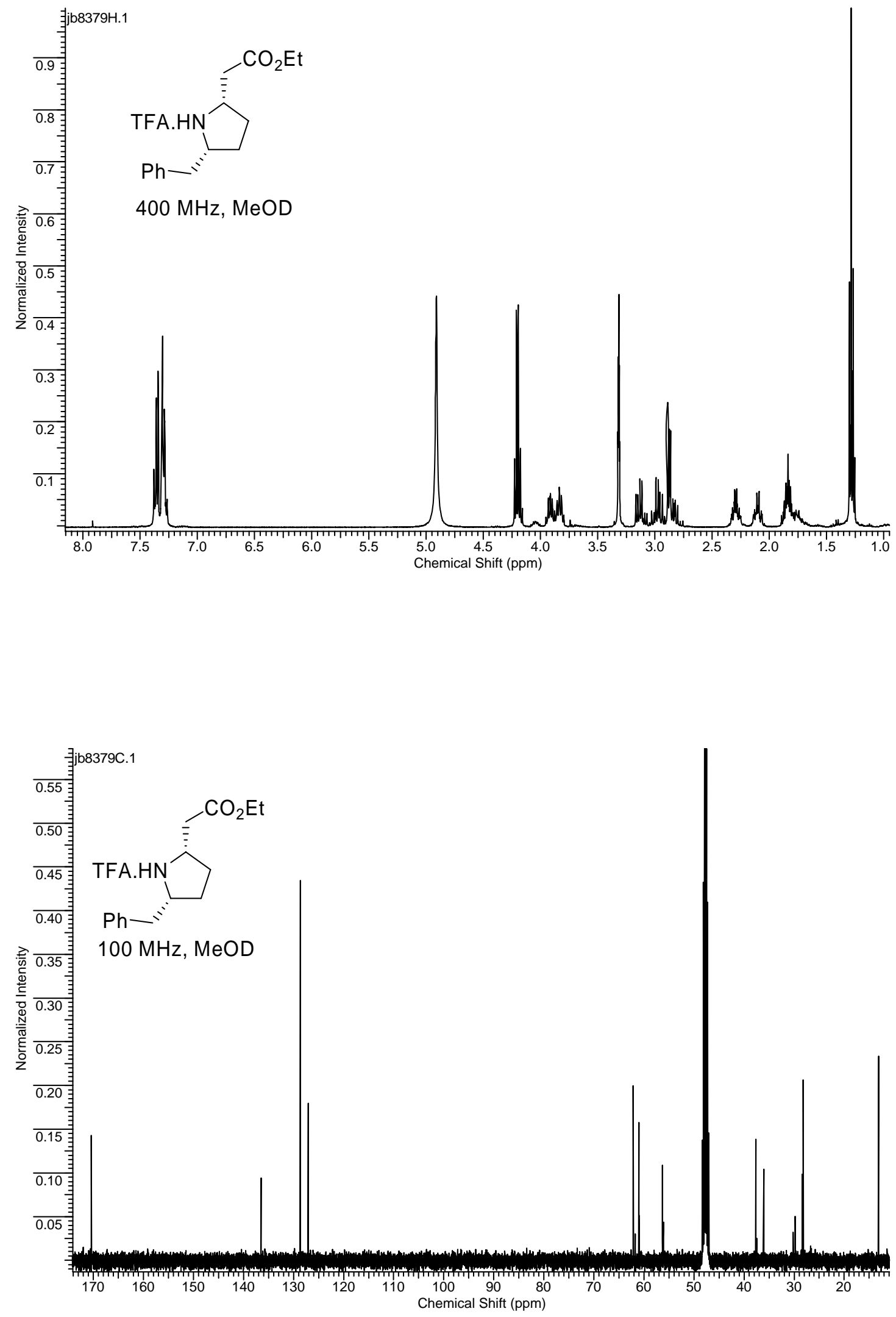